\title{
Large-Scale Agricultural Management and Soil Meso- and Macrofauna Conservation in the Argentine Pampas
}

\author{
José Camilo Bedano ${ }^{1,2, *, \dagger}$ and Anahí Domínguez ${ }^{1,2,+}$ \\ 1 Department of Geology, National University of Río Cuarto, Ruta 36, Km. 601, \\ Río Cuarto X5804 BYA, Argentina; adominguez.unrc@gmail.com \\ 2 CONICET, National Council for Scientific and Technical Research, Buenos Aires C1033AAJ, Argentina \\ * Correspondence: jbedano@gmail.com; Tel.: +54-358-4676229 \\ + These authors contributed equally to this work.
}

Academic Editor: Tiziano Gomiero

Received: 26 April 2016; Accepted: 4 July 2016; Published: 9 July 2016

\begin{abstract}
Soil is the most basic resource for sustainable agricultural production; it promotes water quality, is a key component of the biogeochemical cycles and hosts a huge diversity of organisms. However, we are not paying enough attention to soil degradation produced by land use. Modern agriculture has been successful in increasing yields but has also caused extensive environmental damage, particularly soil degradation. In the Argentine Pampas, agriculturization reached a peak with the generalized use of the no-till technological package: genetically modified soybeans tolerant to glyphosate, no-till, glyphosate, and inorganic fertilizers. This phenomenon has been widely spread in the country; the no-till package has been applied in large areas and has been used by tenants in a $60 \%-70 \%$ of cultivated lands. Thus, those who were involved in developing management practices may not be the same as those who will face degradation issues related to those practices. Indeed, most evidence reviewed in this paper suggests that the most widely distributed practices in the Pampas region are actually producing severe soil degradation. Biological degradation is particularly important because soil biota is involved in numerous soil processes on which soil functioning relies, affecting soil fertility and productivity. For example, soil meso- and macrofauna are especially important in nutrient cycling and in soil structure formation and maintenance, and they are key components of the network that links microbial process to the scale of fields and landscapes where ecosystem services are produced. However, the knowledge of the impact of different agricultural managements on soil meso- and macrofauna in Pampas agroecosystems is far from conclusive at this stage. The reason for this lack of definite conclusions is that this area has been given less attention than in other parts of the world; the response of soil fauna to agricultural practices is complex and taxa-dependent; and there is a wide variety of practices in the main types of agricultural systems, making generalizations difficult. A review of the existing studies on soil meso- and macrofauna in agroecosystems, revealed that (a) agricultural soils, regardless of farming system, are strongly modified in biological aspects compared to the same soils without human interventions; (b) there are no conclusive results about no-till benefits compared to reduced tillage or conventional tillage; (c) agricultural managements that are alternative to the traditional conventional systems are very poorly represented in research.
\end{abstract}

Keywords: Argentina; agriculture; no-till; good agricultural practices; organic farming; genetically modified soybeans; soil biodiversity; soil fauna 


\section{Introduction}

The objective of this review is to explore the reasons behind the conversion of agriculture in the Pampas region of Argentina into a virtual soybean monoculture, and to elucidate the consequences of that process on soil conservation, especially on soil meso- and macrofauna. To accomplish with this objective, this review has been organized into five sections. In Section 1, we introduce general concepts related to the importance of soils for humans as the most basic resource for sustained agricultural production. We point out that our understanding of the soil and our and relationship with it as society is not usually correlated with such importance. We stress the fact that, although modern agriculture has been successful in increasing food production, it has also caused extensive environmental damage and that there are new challenges for future agriculture paradigms. In Section 2, we thoroughly describe and discuss the main characteristics of the most common land uses and management systems applied in the Argentine Pampas as well as the historical contingencies that have led to the current scenario. We revise the idea of "agriculturization" and "soybeanization" in the Pampas associated with the introduction of genetically modified soybeans tolerant to glyphosate together with the no-till technological package. We present important issues about Pampas agriculture: land tenure, the increasing concentration of agricultural production and management, and the large farm units. We then introduce two alternative management systems: the inclusion of "Good Agricultural Practices" (GAPs) in no-till systems and large-scale organic farming. In Section 3, we discuss the context of farming systems at the global level, within which Argentine agriculture is framed, with emphasis on describing impacts and pressures. We claim to move forward from the view of soil almost as an inert supportive medium for agriculture, to new approaches including the notion of soil biology as a key component of agriculture. Specifically, we focus on the role of soil meso- and macrofauna, which are deeply involved in soil functioning through their participation in organic matter cycling as well as in soil ecosystem engineering. However, soil fauna has been historically underestimated and sometimes neglected in conventional farming systems. We urge to think the soil as an ecosystem, with discussions about soil biodiversity and soil functioning. In Section 4 we present a bibliographic analysis of all the papers we found in scientific journals dealing with the impact of different agricultural management practices on soil meso- and macrofauna in the Pampas region. We discuss the main aspects arising from this review in terms of soil fauna as indicators of environmental sustainability in the Pampas. Finally, in Section 5 we provide our main conclusions as well as an outlook for future scenarios.

\section{The Importance of Soils for Humans}

Soil is the most basic of all resources; it is the essence of all terrestrial life and a cultural heritage; however, it is finite in extent and is non-renewable over the human time scale (decades) [1]. Despite its importance for human well-being, politicians, decision makers, scientists and the society in general are not paying enough attention to soils. Indeed, soil has recently been considered a "nearly forgotten resource" [2].

Throughout history, soil has been essential to human well-being. With the transition to agriculture (approximately about 10,000 years ago), human dependence, and impact, on soils became more direct and more obvious [3]. In the history of humankind, there is abundant evidence that the overexploitation of soil and its consequent degradation has been a key factor in the collapse of numerous civilizations that have ignored the conservation of soil e.g., [4]. Soil degradation has certainly been an important issue for ancient civilizations. The earliest farmers, as well as many in later times, practiced shifting agriculture with a long fallow (20 to 30 years). Mobility was their solution to nutrient depletion $[3,5]$. Later, sedentary farmers had to cope with the problem of soil nutrient depletion in a different way. Thus, soil knowledge acquired special importance when and where the population pressure and land shortage impinged [3]. Since then, soil management practices have developed in response to the twin challenges of soil depletion and erosion. Modern soil conservation efforts employ combinations of several techniques, such as ridge planting, conservation tillage, crop rotation, strip cropping, 
grass strips, mulches, living mulches, agroforestry, terracing, contour ploughing, use of cover crops, and windbreaks, all of which had historical precedent $[1,6]$.

Soil and water are the key resources for agricultural production. Soil contains the source of nutrients required for plant growth and is therefore the primary environmental stock that supports agriculture [7]. Currently, in many spheres of policy-makers, politicians, scientists, producers, and in part of the society, a view of soil exclusively as a medium for crop production is still retained. However, based on the wealth of knowledge accumulated in recent decades, a more holistic approach to soil is emerging. Soil not only is a medium for agriculture but also hosts a tremendous abundance and diversity of organisms, ranging from bacteria (a few microns in size) to earthworms (up to several centimetres long). Soil is a key component of ecosystem processes and biogeochemical cycles, and promotes water retention and maintenance of water quality. Moreover, it is a medium where it has been recorded much of the cultural history of humankind. It is well known that without soil, there would be no chance of human life. However, as society, our activities are not consistent with such importance.

Although modern agriculture has been successful in increasing food production, it has also caused extensive environmental damage $[1,6,8,9]$. For example, the misuse of pesticides has led to contamination of land and water, negative impacts on non-target species, and the emergence of pesticide-resistant pests [7]. It is clear that nowadays humans are putting further pressure on the soil. However, there is no consensus about the origin of the increasing pressure. Several reports suggest that the world is facing a "food crisis", which will worsen in the future [10,11]. An increase in global population is expected, from 7.3 billion today to 9.7 billion in 2050 [12]. A change in the life patterns is also expected to lead to a strongly increasing demand for food and pressure on agricultural system [7]. Therefore, there is a generalized claim (and assumption) that we need to increase global food production by $70 \%-100 \%$ in order to feed the world in 2050 [13]. Existing assessments project a combination of intensification of agricultural production and expansion of cultivated land to meet increasing demands for food, feed, fibre and fuel [7]. Experts suggests that approximately $70 \%-80 \%$ of the extra production is projected to stem from intensification and that a major expansion of agricultural land is projected to take place in sub-Saharan Africa, Latin America and East Asia (excluding China) [7]. In a recent review, Foley et al. [10] suggest that production would need to roughly double to keep pace with projected demands from population growth, dietary changes (especially meat consumption), and increasing bioenergy use. The need to "double" production is clearly a powerful statistic that has captured the imagination of policy-makers, politicians, scientists and industry [13]. However, the fact that we need to increase global food production by $70 \%-100 \%$ in order to feed the world in 2050 is being seriously criticised. In a well-argued contribution, Tomlinson [13] stated that an increase in production by $70 \%-100 \%$ was never intended as a normative goal of policy and, moreover, doing so would exacerbate many of the existing problems with the current global food system.

Several other authors suggest that there is not a problem of food demand but of food access $[10,14]$. Perfecto and Vandermeer [15] stated that current worldwide production is enough to provide the necessary calories to feed not only the current world's population, but also the projected nine to ten billion people expected by 2050. Available data indicate that at least one billion people today suffer from hunger and malnutrition [16]; however, this problem may be due to the unequal distribution and the lack of access to food, rather than to the total amount produced worldwide [7,15]. For example, Latin America and the Caribbean (LAC) produce three times the amount of food consumed, but 54 million people are undernourished [17]. Moreover, all the LAC countries, including those with a high rate of malnutrition, have a food energy supply of more than 2000 kilocalories per person per day, which exceeds the minimum recommended for an adult (1815 kilocalories) [17]. Furthermore, data reported in the early 1990s showed that nearly $80 \%$ of the malnourished children from the developing world lived in countries where there were food surpluses [18]. Then, it becomes apparent that hunger and malnutrition in the world today are not due exclusively to the failure to produce sufficient food, but to more complex reasons. Accordingly, it has been suggested that current global food production is sufficient to feed the world, but the undernourished people cannot afford the food [14], partly 
because the increase in food production has not been evenly distributed. Consequently, while the world currently produces enough food on a caloric basis to nourish the global population, food production and access to food vary widely among countries [19]. The great food price volatility is also closely related to that; for example, the number of undernourished people in the world was pushed to unprecedented levels in 2008 and 2009, not because of a crisis in food production but of the world food-price crisis [20]. This shows how price development in food commodity markets can also have a critical impact on global food security. Another factor involved in the complex framework of reasons explaining undernourishment is inefficient food usage. Globally, one third of harvested food is thrown away [14]. Thus, improving post-harvest technologies and reducing food waste are challenges that should be as important as increasing food production. Moreover, one third of harvested food is used for feeding livestock, which are very poor converters of energy into meat [14]; this point poses an important cultural issue related to challenges in dietary changes, which could improve food use efficiency. Therefore, increasing food production is not the only factor involved to achieve the goal of reducing world hunger.

Land degradation is the decline in land quality or reduction in its productivity and can be estimated in terms of the loss of actual or potential productivity or utility as a result of natural or anthropic factors [21]. Thus, land degradation is now a major global issue, since global estimations highlight that soil degradation is affecting 33\% of all soils in the world [22]. There are four main types of soil degradation [1]: (i) Physical; (ii) chemical; (iii) biological; and (iv) ecological. Soil physical degradation results in a reduction in structural attributes, with degraded soils showing increased susceptibility to crusting, compaction, reduced water infiltration, increased surface runoff, wind and water erosion, greater soil temperature fluctuations, and desertification. Soil chemical degradation is characterized by acidification, salinization, nutrient depletion, reduced cation exchange capacity, leaching of essential plant nutrients, and pollution. Soil biological degradation reflects depletion of the soil organic carbon pool, loss in soil biodiversity, a reduction in soil C sink capacity, and increased greenhouse gas (GHG) emissions. Ecological degradation reflects a combination of the other three types, and leads to disruption in ecosystem functions, such as elemental cycling, water infiltration and purification, perturbations of the hydrological cycle, and a decline in net biome productivity.

The overall decline in soil quality, due to both natural and anthropogenic factors, has strong consequences that jeopardize ecosystem services and nature conservation [1]. Although a few ecosystem services have improved globally since the expansion of conventional agriculture, such as provision of food and timber, many other services are compromised. For example, flood control, genetic resources, or pollination [23]. Modern agricultural practices may be trading short-term increases in food production for long-term soil degradation, with important losses in ecosystem services, including many that are important to agriculture itself [8]. Soil degradation implies a decline in soil quality with an attendant reduction in ecosystem functions and services [1]. For example, soils mediate services like soil formation, nutrient cycling, primary production, climate regulation, flood control, detoxification, protection of plants against pests, etc. [24]. These services are provided by a large range of organisms [24,25], but soil biota is being negatively affected by inadequate land uses around the world [26]. Thus, paradoxically, by inadequately applying land uses and management practices, humankind is degrading the soils of the world, while becoming more dependent on soil as a natural resource for subsistence.

\section{Land Uses and Management Systems in Argentine Pampas}

Argentina is the southernmost country of South America region. It covers an area of 2,766,890 $\mathrm{km}^{2}$, of which about $15 \%$ are arable lands and permanent crops, about $40 \%$ are permanent meadows and pastures, $10 \%$ corresponds to forest cover and the remaining $35 \%$ has another uses [27]. Population is of 42.16 million people, with only $6.92 \%$ being rural population. This implies a very low proportion of inhabited rural land, unlike other countries of Latin America and the Caribbean. Indeed, the peasant 
community is small and mostly scarcely involved in agricultural management decisions. Soybean is the main agricultural commodity: 40,100,197 tons were produced in 2012 [27].

Argentina holds 18 ecoregions (Figure 1). Among them, the Pampas is a wide plain with more than 52 Mha of lands suitable for cropping and cattle rearing, and whose high fertility and productivity provide significant comparative advantages for agricultural production [28,29]. The Pampas region is the most important agricultural area in Argentina and one of the six major grain-producing areas in the world (along with North America, Western Europe, Ukraine-Russia, China, and Australia) [30]. The main crops produced in the country, including the position in the world rank, are presented in Table 1.

Table 1. Main crops produced in Argentina and comparison with the major grain-producing countries in 2013 [26]. The number in parentheses indicates the position of each country in the world rank for each crop.

\begin{tabular}{|c|c|c|c|c|c|}
\hline Crop & Argentina & USA & Brazil & China, Mainland & India \\
\hline & \multicolumn{5}{|c|}{ Production (tons) } \\
\hline Soybean & $49,306,200(3 \mathrm{rd})$ & $91,389,350$ (1st) & $81,724,477$ (2nd) & $11,950,500$ (4th) & $11,948,000$ (5th) \\
\hline Maize & $32,119,211$ (4th) & $353,699,441$ (1st) & $80,273,172(3 \mathrm{rd})$ & $218,489,000$ (2nd) & $23,290,000$ (6th) \\
\hline Sugar cane & $23,700,000$ (13th) & $27,905,910$ (10th) & $768,090,444$ (1st) & $128,200,912(3 \mathrm{rd})$ & $341,200,000$ (2nd) \\
\hline Wheat & $9,188,339$ (17th) & $57,966,656$ (3rd) & $5,738,473$ (23th) & $121,926,400$ (1st) & $93,510,000(2 \mathrm{nd})$ \\
\hline Barley & $4,705,160$ (9th) & $4,682,735$ (10th) & 330,682 (38th) & $1,699,300$ (19th) & $1,750,000$ (18th) \\
\hline Sorghum & $3,635,837$ (5th) & $9,881,788$ (1st) & $2,126,179$ (8th) & $2,891,500$ (6th) & $5,280,000(3 \mathrm{rd})$ \\
\hline Sunflower & $3,104,420$ (3rd) & 917,060 (12th) & 108,838 (27th) & $2,423,241$ (4th) & 504,000 (17th) \\
\hline
\end{tabular}

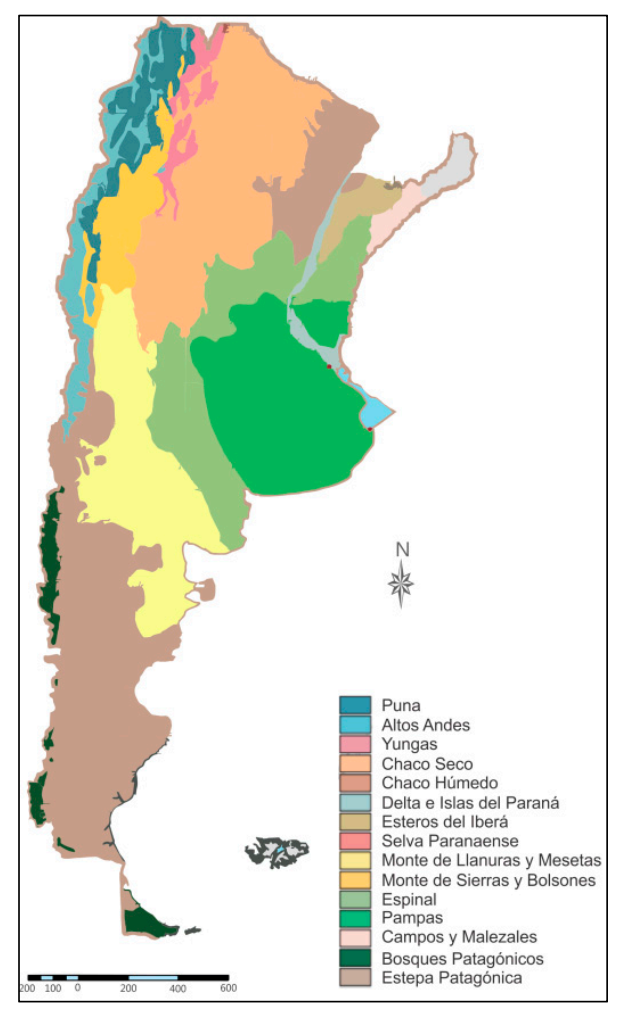

Figure 1. Map of the ecoregions of Argentina showing the location of Pampas region (Modified from [31]).

The region has a relatively short farming history: most of the area was native grassland until the beginning of 20th century, when land use changed into cattle raising and crop production. The agricultural and grazing lands of the Pampas were the basis of the economic development and well-being of the Argentine population in the 1880-1910 period [32]. Alternating cattle raising on native grasses or alfalfa pastures with agriculture based on a wheat and maize rotation used by Argentine farmers and ranchers turned out to be a very sustainable technology [32]. Over time, 
agriculture slowly became more profitable than cattle raising, and the grazing-agriculture rotation was abandoned in those soils that were suitable for agriculture [32]. Historically, the proportion of cattle raising and mixed and purely agricultural management systems varied according to the international price of the products and the domestic demand. At present, grain agriculture dominates farming activities because it has become more cost-effective than cattle raising. Thus, "agriculturization", i.e., a strong and continuous increase in the land area dedicated to crop growing, began in the Pampas. This process was slow at first, in the 1960s, with an increase in the cultivation of areas previously dedicated to cattle raising [29]. Since the early 1990s, structural economic changes fostered investment in technology, which played a major role in land-use changes in the Pampas [29]. However, in Argentina, agriculturization was dramatically intensified after 1996 (Figure 2), with the introduction of the genetically modified (GM) soybeans with glyphosate-tolerant genes. This soybean variety is not affected by the herbicide glyphosate and thus it can be used for controlling weeds at any physiological stage of soybean crop $[33,34]$. Associated with the increase in agricultural area, there was a parallel process of concentration and intensification of cattle production [29]; thus, the overall number of cattle did not decrease, but became concentrated. Concentration followed two alternatives: an increase in the number of feedlots or the relocation of cattle in more marginal land, where crop production is less profitable, unfeasible or more hazardous [35]. Indeed, number of cattle heads was $50.9 \mathrm{M}$ in 2013, and 50.8 in 1996 [27]. Over a 10-year period (2001-2011) 14 million ha of cattle land were converted into agricultural land [36]. Nowadays, $80 \%$ of total bovines heads raised in feedlots is concentrated in Buenos Aires, Santa Fe, Córdoba and Entre Ríos, three of the Pampas provinces [37].

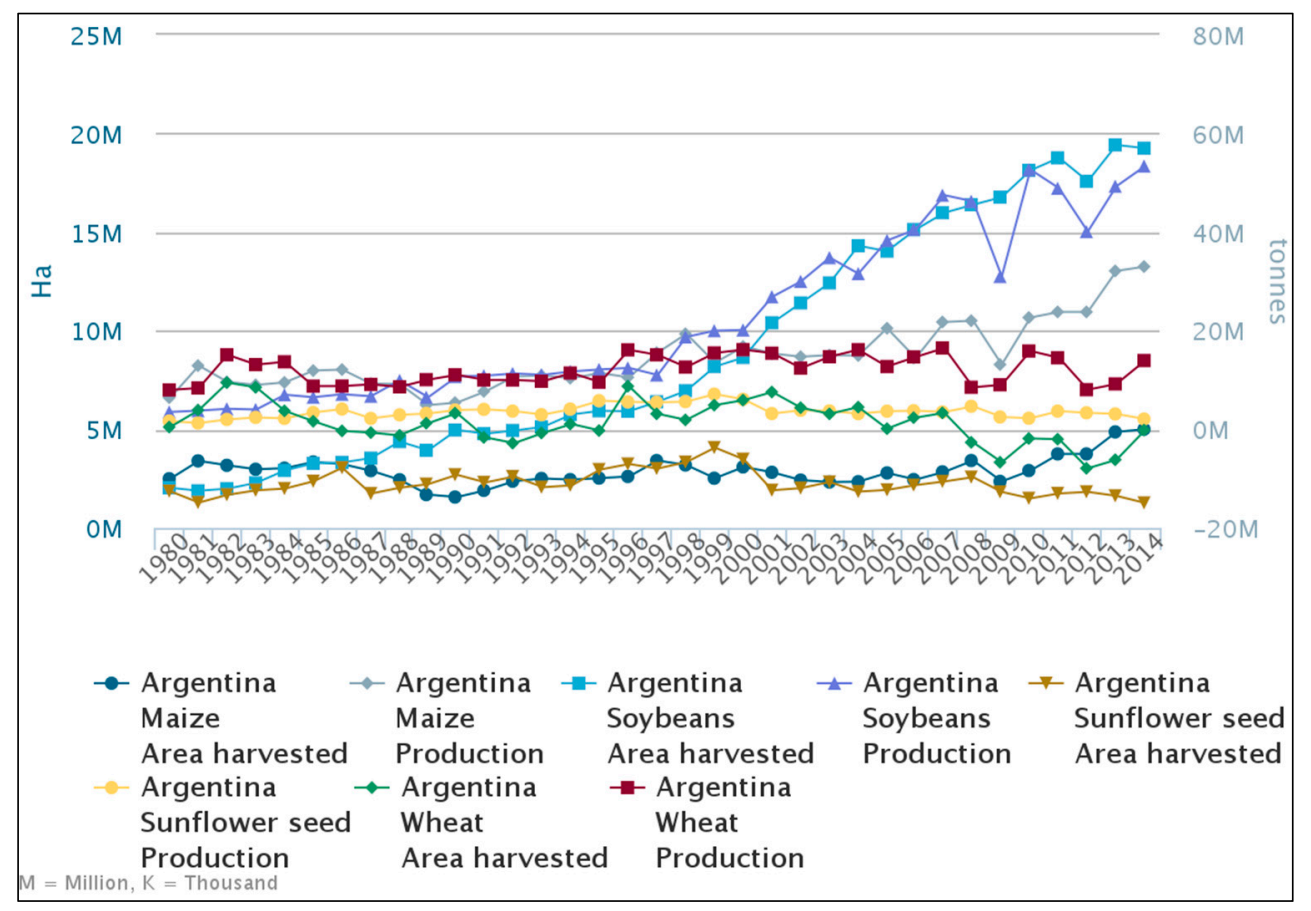

Figure 2. Harvested area (Ha) and production (tonnes) of the four main crops grown in Argentina from 1980 to 2014 .

By the mid 2010s, GM varieties represented over $90 \%$ of the area planted with soybeans and $70 \%$ of that with maize. Throughout this process, Argentina has become the second largest producer of GM crops, after the United States [38]. The process of GM crop adoption developed at an unprecedented rate, only comparable to the case of hybrid maize in the state of Iowa (USA) during the 1930s [38]. The expansion of soybean in Argentina has been particularly impressive. It was introduced in the early 1970s; by 1990, the soybean area reached 5.1 Mha, expanding to 14.0 Mha in 2005 and to 20.3 Mha in 2014. Soybean production has grown from approximately 11 million tons in 1993 to 35 million tons 
in 2003 and 50 million tons in 2013 [39] (see Figure 2). A decrease in production occurred in 2008/09 because of severe climate conditions. The current average yield in the Pampas region is $33 \mathrm{qq} / \mathrm{ha}$, ranging from 31 to $60 \mathrm{qq} / \mathrm{ha}$, and depends mainly on whether soybean is the only annual crop or is in rotation with a winter crop (mostly wheat). Argentina is currently the third top producer of soybean in the world, after U.S. and Brazil (Figure 3). Benefits of this commodity were on average about $530 \mathrm{U} \$ /$ ha for 2013/14 [40].

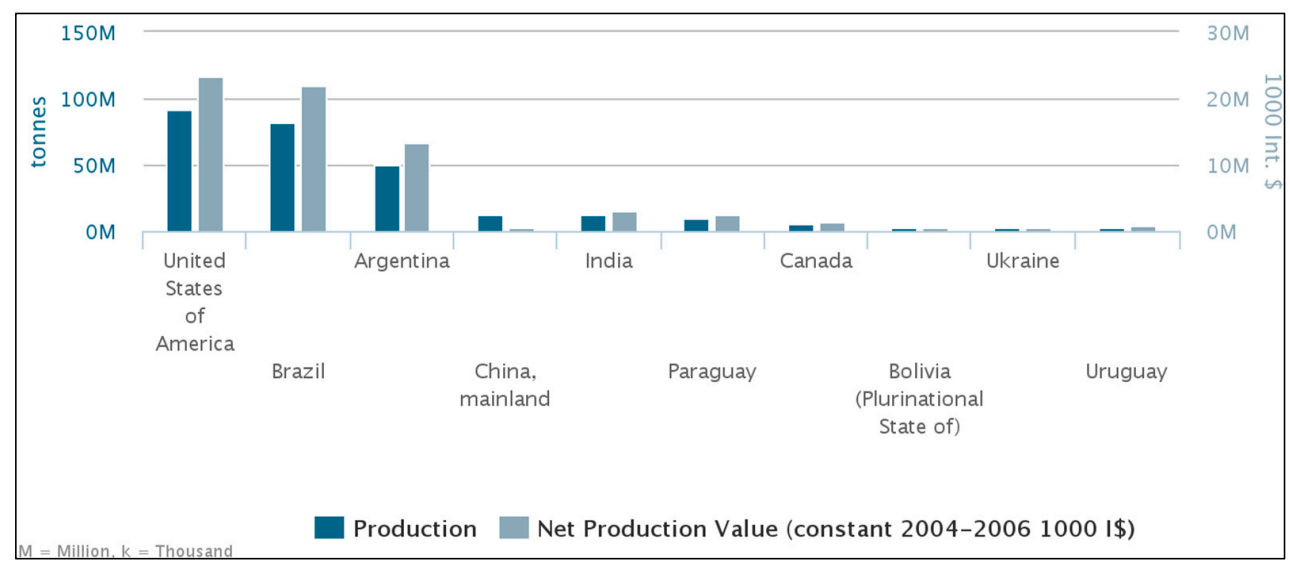

Figure 3. Argentine production of soybean in relation to main soybean-producing countries.

During this period, soybean crop displaced other crops (maize, sunflower), pastures, grasslands and forests, thus becoming the most important commodity in the country (Figure 4). Soybean is currently more profitable than other crops, requires less investment (due to lower costs associated with GM varieties) and labour, and has significantly lower production risk than alternative enterprises [28]. However, the main driver for increased soybean production has been the higher price than that of other grain crops [39].

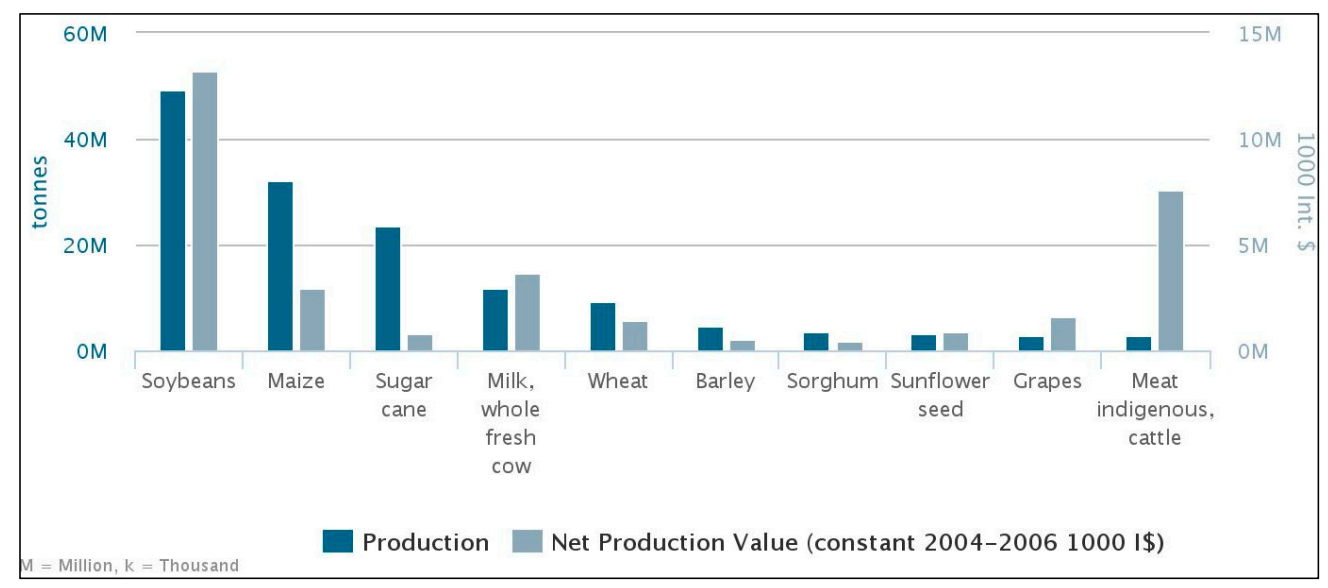

Figure 4. The ten principal commodities produced in Argentina (elaborated with data from the Food and Agriculture Organization of the United Nations Statistics Division (FAOSTAT) [27]).

The expansion of GM soybean in Argentina is highly correlated with the expansion of no-tillage (NT) practices (0.90) [41]. Indeed, the complete technological package related to the current soybean dominance in Argentine agriculture, known as the "no-till package", comprises the glyphosate-tolerant GM soybean, no-till, glyphosate, and inorganic fertilizers. The agriculturization process, as well as the posterior embracing of the no-till package, is closely related to one of the most contentious social, political, and historical issues about the Pampas: land tenure. The early colonial pattern of large land holdings (10,000 ha being a small holding, some extending up to 500,000 ha) was related to a system of 
sharecropping agriculture with immigrant farmers that developed after 1860 [32]. From the beginning of the 19th century to the 1960s, the average size of a holding decreased steadily; but this trend was reverted after the 1960s. Thus, the average farm size in the Pampas in 1914 was 355 ha, in 1988 was 370 ha [32] and then, between 1988 and 2002, a strong concentration in land tenure occurred, with the average production unit area increasing to 533 ha [42]. The increasing concentration of agriculture production and management was the key factor leading to the process of agriculturization [29].

Nowadays, the landscape in the Pampas region is mostly dominated by large (about 1000 ha) and medium-sized (about 500 ha) farms producing a few crops, with most of the management decisions being dependent on market forces. This is in contrast to what happens in other Latin American countries, where small-scale owners still represent a large percentage of the agricultural landholdings [43], as well as in other regions of Argentina. Thus, the big size of farms and plots within farms is a very important characteristic of the Pampas region. About $3 \%$ of the producers are responsible for $70 \%$ of soybean production in Argentina, with much of this production corresponding to sowing pools [35].

As a consequence of concentration of agriculture production and management, very often much of the area planted is not owned by those cultivating it [29]. Indeed, the great economic investment that requires a no-till planting machine makes units smaller than 200 ha [44] non-profitable. Thus, for small and medium land owners, renting land has been a more profitable activity than producing crops. This is also a key factor regarding management decisions that have strong implications for agricultural sustainability. Most of the mentioned farms are rented to local actors (neighbours or area residents), agricultural companies or sowing pools. Sowing pools are speculative investment funds that work for a fixed period on a surface area that exceeds the normal size of the surface areas operated locally or regionally by other capitals. They lease all the land on which they operate and hire third-party services for all the activities involved in the production process: Planting, agrochemical application, maintenance, tilling and harvesting services [45]. Although there are no official statistics, independent estimates indicate that sowing pools farm about $20 \%$ of the land planted with soybean and the total area operated by tenants reached more than $50 \%$ by 2005 [44]; and about $60 \%-70 \%$ by $2014[46,47]$. Thus, those using the land make choices during the annual cropping cycle that have consequences that may not become evident until later, when the land is or is not farmed by the same lessee. The problem arising under this scenario is that there are strong incentives to maximize short-term profits via agriculture and may discourage sustainable practices such as ecologically sound crop rotation [29]. It has been shown that land tenants are more likely to crop soybean, which requires lower initial investment, and that they are less concerned about soil quality maintenance and other environmental issues than landowners [48].

Another important point in this scenario is that production concentration in the Pampas arose together with an increasing influence of the commercial strategies of international corporations on agricultural management decisions. In the Pampas, knowledge governance has evolved through two historical phases. The first phase was dominated by the National Institute of Agricultural Technology (INTA), a governmental research and extension institute. The second, and current, phase is characterized by the collaboration between public and private actors mediated by farmer organizations [49]. For example, the market of seeds, biocides and fertilizers shows a strong presence of multinational enterprises along with the de-structuring of previous domestic supply, an active investment process, control of a significant part of the marketing chain by producers of key materials, and an emphasis on imports and the transference of relevant technologies from abroad, with adapting participation from local agents [50]. With this profile of the supply of inputs and services, the structure and functional dynamics of the agricultural activity begins to be reconfigured in favour of a model focused on a greater incidence of input suppliers in establishing the role of production (what to sow and how) and in its development (through outsourcing contracts) [50]. For instance, Monsanto has played a crucial role through its production of glyphosate in Argentina since 1982. This corporation has actively promoted technological packages combining no-tillage with glyphosate-resistant soybeans 
and has sponsored research activities along with INTA, farmer organizations, and individual farmers and researchers [49]. Moreover, these kinds of companies offered comparative advantages to large farmers for purchasing agricultural inputs and machinery, and provided significant technical assistance throughout their wide networks of product distribution [50]. Thus, the international corporations have changed their traditional role of providers of agricultural inputs to that of highly influential actors in agricultural production and commercialization.

Besides the land tenure issue, another crucial aspect of the Pampas production system is the weakness of the public sector and the lack of agricultural policies, which finally promote comparative advantages to large farmers and results in a tacit transfer of responsibilities, such as strategic production decisions, from the government to technical NGOs and agribusiness corporations [29]. The term "soybeanization" has been recently proposed to name the modern, most extreme form of agriculturization that has transformed land tenancy structures, displaced certain agricultural actors and created new others, and ultimately changed the relationship between agriculture and the rest of the society and the territory [44].

However, together with the noticeable economic benefits of the intensive no-till soybean agriculture, this system had to face some important problems. For example, along with an increase of overall productivity, there has been a loss of crop diversity (i.e., conversion of long-term perennial pastures to grain crop rotations or even monocultures) and an unprecedented expansion of cropland devoted solely to soybean production into marginal areas [41]. There is also controversy over the no-till package regarding the wide use of herbicides to control weeds and of the GM crops. For example, in Argentina, the agricultural area increased from 24,055,641 ha in 1995 to 35,901,599 ha in 2011, representing an increment of cultivated area of about 49\% [51]. However, herbicide use [27] increased from 24,863 tons of active ingredient in 1995 to 212,337 tons in 2011, representing an increase of about $750 \%$. Indeed, this increase is very similar to that of no-till surface, which in the same period had an increase of about $800 \%$ (from 3 Mha to $27.5 \mathrm{Mha}$ ). These data show how the adoption of the no-till package has implied a very much higher increase in herbicide use than the increment in agricultural lands area. In the last years, there has also been an increasing concern for the human health due to the exposure of entire populations to agrochemicals applied in association with the adoption of no-till and GM crops. This concern has especially increased since the International Agency for Research on Cancer (IARC), the specialized cancer agency of the World Health Organization, re-categorized glyphosate as probably carcinogenic to humans (Group 2A, [52]). There are also studies dealing with the impact of glyphosate on soil fauna, especially earthworms, but results are far from conclusive. Several studies consistently found very low mortality of the worms Eisenia andrei and Aporrectodea spp. at recommended (from $1440 \mathrm{~g}$ ai/ha to $1800 \mathrm{~g}$ ai/ha) and higher rates of glyphosate [53-60]. García-Torres et al. [60] reported significant mortality at only very high concentrations $\left(50,000 \mathrm{mg} \cdot \mathrm{kg}^{-1}\right)$. Finally, Piola et al. [61] found that lethal rates depended on commercial herbicide formulations. Regarding reproduction parameters, the number of juveniles and/or cocoons decreased at rates of 1 to $1000 \mathrm{mg} \cdot \mathrm{kg}^{-1}$ [55], $5000 \mathrm{mg} \cdot \mathrm{kg}^{-1}$ [60] and $1440 \mathrm{mg} \cdot \mathrm{ai} \cdot \mathrm{ha}^{-1}$ [54]. However, other studies found no significant effects of glyphosate on measured earthworm reproduction parameters [53,56,57,62]. Santadino et al. [63] observed a significant increase in the number of E. fetida cocoons with increasing glyphosate doses. The effect of environmental rates of aminomethylphosphonic acid (AMPA), one of the two major breakdown products of glyphosate, on E. andrei, was assessed by Domínguez et al. [64], who found no mortality but reproductive disorders.

Regarding the consequences of no-till on soil structure, compaction of the topsoil under no-till systems has been described in several studies in the Pampas region, when compared to other tillage systems in similar crop rotation schemes. For example, higher bulk density values in no-till than in tillage systems have been reported [65]. It has also been found that no-till can promote shallow compaction in fine textured topsoils [66]. Buschiazzo et al. [67] compared conventional tillage with conservation tillage and observed higher organic matter content in conservation tillage, but significantly higher bulk density than in conventional tillage. Domínguez and Bedano [68] found an 
increase in bulk density in NT regarding natural grasslands, plough tillage and organic farming, in the first $10 \mathrm{~cm}$ soil depth. Figure 5 shows an example of the compaction of the first 10 centimetres of soil under NT systems in Argentina.

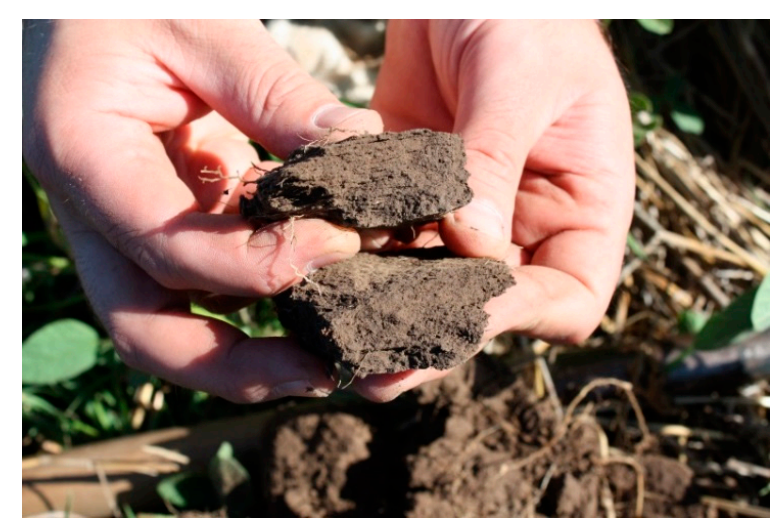

Figure 5. An example of compacted soil under no-till systems in Argentina, showing a laminar structure.

At present, there is also concern about the previously undisputed idea of higher yields in NT than in conventional tillage systems. Pittelkow et al. [69] conducted a global meta-analysis to evaluate the influence of various crops and environmental variables on no-till relative to conventional tillage yields. Their results show that no-till performance is highly context-dependent. For example, no-till resulted in maize yield declines in tropical latitudes but increased yields relative to conventional tillage systems in arid regions, where there is water restriction for crop growth.

In the first years after the spread of no-till, and in the economic context related previously, most of the Argentine farmers began to use a no-till management practice that differed from the recommended by the no-till researchers. From a theoretical point of view, to be a conservative management practice, no-till needs to be accompanied with a group of management strategies, such as retention of crop residue mulch, the incorporation of a cover crop in the rotation cycle, and the use of integrated nutrient management $[1,70]$. However, in the Argentine Pampas, no-till management is mostly restricted to the use of GM crops, no-till-seeders and a chemical fallow during the winter season. Furthermore, soybean monocropping, the absence of cover crops, and residue grazing are very common practices. This can be considered the clearest expression of the soybeanization phenomenon, which is evident in Figure 6 . Field observations showed the almost bare soil surface due to the scarce soybean stubble, a situation that is worsened by cattle grazing or by harvesting crop residues for cattle consumption. In these farms, several studies have shown clear evidences of soil erosion and degradation. For example, an $82 \%$ reduction of organic $\mathrm{C}$ regarding a reference soil was observed by Cantú et al. [71]. The sharp decline in organic $C$ content has been observed in other investigations in the region [72,73]. A reduction of about $70 \%$ in the thickness of A horizon in comparison with the reference soil was also observed. This is mainly due to water erosion processes that have been estimated by means of erosion models [74] and direct field measurements [73]. Regarding soil biological degradation, a decrease in the abundance of some groups of mites and springtails and a change in the proportion of mite suborders [75] and changes in taxa dominance [76] were observed in NT. Similar changes were observed for soil macrofauna taxa: earthworms, beetles, spiders and ants $[77,78]$. The changes in soil biota were related to an increase in bulk density, a reduction of soil organic $\mathrm{C}$ content, a reduction of abundance and heterogeneity of soybean stubble as well as to the effect of agrochemicals [76-78]. Moreover, in the entire Pampas region, these no-till management practices have led to several degrees of physical and chemical soil degradation [65].

The no-till soybean monocropping has continued until present in many farms in the Pampas, fostered by comparatively good prices of soybean in the international market, and in many cases associated with the important increase in land leasing that was discussed earlier. In view of the degradation processes associated with soybean monocropping and of the increasing criticism to the 
no-till system, a group of farmers organized the Argentine No-till Farmers Association (AAPRESID). Approximately in 2008, they started to adopt and promote those agricultural practices they considered necessary to comply with NT system: crop rotation; cover crops; integrated pest, weed and disease management; nutrient restoration; and a rational use of agrochemicals. This group of practices is called "Good Agricultural Practices" (GAPs), in accordance with the definition of "Conservation Agriculture" by the Food and Agricultural Organization (FAO) described in Poisot et al. [79]. Nowadays, AAPRESID considers that only when all the GAPs are implemented is management considered a "no-till system" and can therefore achieve high productivity, while maintaining the production capacity of resources [80]. However, Alvarez and Steinbach [81] performed an exhaustive review and concluded that the adoption of no-till had no impact on soybean yield in humid Pampas agroecosystems. Equal yields of wheat and corn can be also attained in the Pampas using different tillage management strategies that include enough nitrogen fertilizer. Thus, they sustained that crop yield increases obtained during the last decades in the Pampas do not seem to be related to the massive no-till adoption but to the application of fertilizer technology, genetic gains and other improved management strategies. Accordingly, despite the wide promotion of GAP benefits by AAPRESID, no-till with GAPs is a system currently applied in a small proportion of the Pampas, accounting for no differences in crop yield between NT applied without GAPs and other tillage systems. Regardless of the two NT approaches-with or without GAPs—soil fauna activities are crucial to this system. Indeed, soil micro-organisms and soil fauna are taking over the tillage function and soil nutrient balancing in no-till systems [82], since, no mechanical tillage is performed, that can improve organic matter incorporation or soil loosening. FAO considers that conservation agriculture (NT with GAPs) is only possible when soil organisms carry out the task of tilling the soil [39]. However, the dependence of NT on soil organisms is paradoxical, since NT also strongly depends on the use of chemical farm inputs. Accordingly, the recommendation of FAO is that synthetic pesticides and mineral fertilizer have to be used in a way that does not harm soil life. In the FAO proposition for conservation agriculture, weed control is thought as a problem to be solved mainly by means of permanent soil cover with crop residues or cover crops. In addition, soil nutrition is strongly related to cover crop together with sound crop rotation, and promotion of a very active soil biota community. The avoidance of pest and diseases are also achieved through crop rotation, by interrupting the infection chain between subsequent crops. According to FAO, this can be attempted sometimes with transitions periods of lower yields, until a new equilibrium between the organisms of the farm-ecosystem, pests and beneficial organisms, crops and weeds, becomes established. However, FAO also mentioned the surface under NT in Argentina and other countries as an example of success of "conservation agriculture" [82]. Accordingly, it is important to highlight that in Argentina, NT is, as we detailed previously, strongly related to transgenic resistance to herbicides, and highly dependent not only on herbicides but also on insecticides and fungicides. The dependence upon herbicide-resistant varieties is evident in the increasing concern on herbicide-resistant weeds [83-85]. Moreover, AAPRESID has created a resistant weeds knowledge network to deal with this problem [86]. The early mentioned paradox creates a difficult scenario, because the main argument to adopt NT is that it allows, in fact it needs and relies on, a healthy soil biota community. Thus, in Argentina, there are persistent doubts about how a healthy soil biota community will be achieved in an agricultural scenario strongly dependent on agrochemicals. Some studies have shown that no-till can affect soil fauna community through the concomitant heavy use of toxic agrochemicals, as well as through changes in soil physical, chemical and physicochemical properties [87-89]. Compaction recovery is not easy in no-till soils $[65,66,90]$, which depend on soil biological mechanisms to reach a loosened condition. Therefore, it has been suggested that a better understanding of biological mechanisms is needed, with particular focus on the role played by plant roots, soil microorganisms and meso- and macrofauna in the recovery of soil structure [7].

As we described previously, at present, no-tillage is the most widely used farming system in the Pampas region, in a range varying from soybean monoculture to GAPs application, but all of them included in the paradigm of conventional or industrial agriculture, with a high dependency on synthetic agrochemicals. However, in the last 20 years, certified organic farming increased about five 
times in agriculture and almost 30 times in cattle production [91]. Nowadays, 2.8 Mha are dedicated to organic cattle production in Argentina and 200,000 ha are dedicated to agriculture, with most of these agricultural organic lands being also located in the Pampas region [91]. Organic farming aims to maximize the reliance on farm-derived renewable resources and on the management of ecological and biological processes and interactions, so as to provide acceptable levels of crop, livestock and human nutrition, protection from pests and disease, and an appropriate return to humans and other resources [92]. Hence, this production system is intrinsically compromised in order to meet the objective of a sustainable agriculture [93]. An important concept underlying organic agriculture is that the reduced use of external inputs is sustained by the maintenance and development of self-regulating processes [94]. Thus, the organic farming system strongly relies upon soil functioning, in which soil fauna have a crucial role. Despite the relevance of this system in the global search for a more environmentally sound agriculture, in a recent review, Tuck et al. [95] highlight that the effect of organic farming on soil organisms is still ambiguous and in general poorly studied, especially in South America, although an important proportion of world organic production is performed in this region.

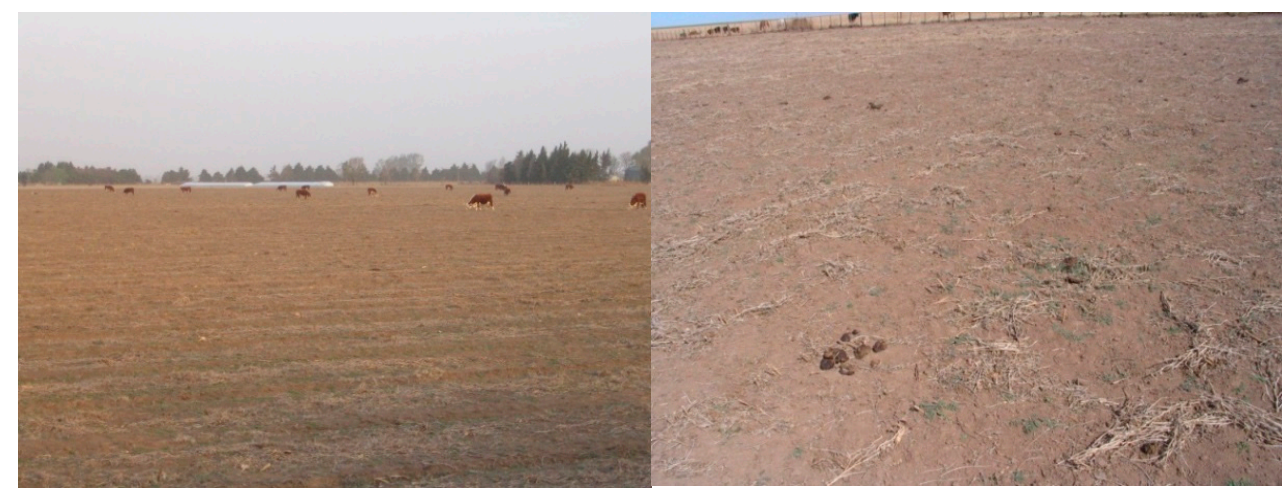

Figure 6. The in-field results of the soybeanization process in the west portion of the Pampas region. (A) Cattle grazing on the originally poor soybean stubble; (B) Soil surface almost bare and visibly degraded by the combination of soybean monocultutre and cattle grazing.

\section{The Present Situation of Farming Systems: Impacts and Pressures}

Beyond the discussion conducted in Section 1 about the need of an increase in agriculture production, and how to cope with this, agriculture has to face serious environmental issues. Until recently, most agricultural paradigms have focused on improving production, often with detrimental consequences for the environment [10]. Hence, agricultural sustainability is now at considerable risk because the already accomplished loss of soil biodiversity has led to a reduced capacity of current agroecosystems for self-regulation and, therefore, to an increasing dependence on external inputs, which can only bypass a limited number of biological processes [25]. To achieve global food security and environmental sustainability, agricultural systems must be transformed to address both challenges [10]. Here we face a paradox: The solution from conventional agriculture for increasing production is to intensify agriculture, which is known as the most important reason for environmental degradation. Therefore, there is a need for new approaches, including modifying conventional agriculture and adopting lessons from organic systems and precision agriculture [10]. Although beyond the scope of this paper, it is important to consider the social issues that are involved in the need to change the conventional agricultural paradigm. We have repeatedly mentioned the concept of "food security" in this paper, as a goal that is leading the discussion on agricultural paradigms presented here. At this point, it is important to mention the concept of food sovereignty, precisely in order to include social consideration in the present discussion. Food security simply refers to a situation in which all people of a given spatial unit, at all times, have physical and economic access to safe and nutritious food that is sufficient to meet their dietary needs and food preferences for an active and healthy life, and that is obtained in a socially acceptable and ecologically sustainable manner [7]. Instead, 
food sovereignty is defined as the right of peoples and sovereign states to democratically determine their own agricultural and food policies [7]. This broader concept obviously includes the need for ensuring food security, but it also highlights the right of societies to be part of the decision process regarding how to achieve that food security. Accordingly, the actual dominant agronomic paradigm in Argentina (conventional/industrial agriculture) has greatly minimized the influence of most of the society and even of governmental institutions. The current agriculture paradigm is related to loss of jobs, pauperization of rural employment, erosion of cultural patterns, effects on land concentration, loss of productive diversity, increased external dependence, devaluation of work in the region, land foreignization, patenting on biodiversity and loss of local access, knowledge appropriation, and many other issues associated with the loss of food sovereignty [96]. However, these social issues related to agriculture are very often neglected and macroeconomical aspects are normally priorities for decisions makers involved in agricultural issues in Argentina.

However, the mentioned social issues are important when considering the need for a change of paradigm, because alternative agriculture paradigms are being proposed for redounding not only in the maintenance of soil as a system capable to continue production at high levels but also in a healthier environment for soil biology and human populations as well. In this sense, organic and/or agroecological alternatives have a lot to contribute to this debate.

In general, a new concept of biological fertility of soil is arising, which interprets fertility as the availability of nutrients for plants as a result of flows of different nutrient forms and transformations into the soil, both mediated by soil biology [51]. The inclusion of biology in the concept of soil fertility has been an important advance, but a further conceptual broadening is needed to manage soils in a sustainable way [97]. At present, when soil biology is considered a key component of sustainability, the idea of "soil biology" is still mainly related to "soil microbiology". Scientists quite often acknowledge microbial activities as the mediators of over $90 \%$ of nutrient mineralization and dominant actors in biogeochemical cycles [24]. However, they pay much less attention to the roles of invertebrates: the real conductors of microbial symphonies that shape their communities and tune their activities in complex multi-scale interactions [24]. Assigning a main role to those interactions is one of the major challenges in the pursuit for a new agricultural paradigm. Earthworms strongly enhance microbial activity in their casts, indicating that there are hot spots for soil microbial dynamics and increasing habitat heterogeneity for soil microorganisms [98]. It has been suggested that earthworms mediate small-scale patchiness of the soil microenvironment by redistributing soil microbial biomass and activity in space and thereby contribute to spatial heterogeneity in soil nutrient processes [99]. Moreover, in agroecosystems, and especially in no-tillage, these earthworm-mediated controls of the spatial patchiness of soil processes may be important because crop residues are maintained on the soil surface [99].

However, the current technology and advances used to increase agricultural production have largely ignored soil invertebrates as an essential component of management. In conventional farming systems, little attention has historically being paid to their importance in soil, leading to a huge loss of biodiversity and therefore of its functions, which are key to maintaining the quality of the resource. In general, three main aspects of agricultural management negatively affect soil fauna: habitat loss (through soil compaction), food resource depletion (decrease of soil organic matter, poor and homogeneous soil cover) and the effect of large amounts of agrochemicals [24,77,100-102]. By affecting soil organisms, agricultural practices affect the functioning of the ecosystem and ultimately, soil quality, affecting the future capability of soil to continue being productive.

Beyond the discussion about the need for changing the current agriculture paradigm, which seems to be increasingly clearer among the scientific community, is the mentioned importance of soil biota for maintaining and improving of soil quality, and therefore of soil productivity, through biological processes. Restoring soil biological processes is the key to achieving lasting food and environmental security [97]. Therefore we identify a great need that farmers, decision makers and society consider soil biodiversity as the root of sustainable agriculture. It has been widely recognized that soil biota is a key component of a strategy towards agricultural sustainability. Soil biota is involved in disease 
suppressiveness, resistance and resilience against disturbances and stress, improvement of water and nutrient use efficiencies, among others soil biological processes (e.g., [25,103,104]), thus improving soil fertility and land productivity.

Soil communities are extraordinarily diverse and abundant. Soil hosts a quarter of the planet's biodiversity, and supports, directly or indirectly, a high proportion of the rest. Soil biological communities include organisms from almost all the principal taxonomic groups found in terrestrial ecosystems. Soil organisms probably represent as much as $25 \%$ of the 1.5 million living species described worldwide [56]. The huge differences in the size of soil organisms, ranging from about $3 \mu \mathrm{m}$ for bacteria to more than $15 \mathrm{~cm}$ for earthworms, are also noticeable.

Despite their crucial contribution to global biodiversity, soil organisms have only weakly engaged the attention of taxonomists compared with other groups, such as higher plants and vertebrates [105,106]. Below-ground taxa suffer from a conspicuous deficit of interest from the scientific community and we still know very little about their taxonomy, systematics and biogeography. Taxonomic deficit for soil biota is on average $76 \%$ and tends to increase for small-bodied taxa [105]. This deficit is especially serious in Argentina because there is a lack of taxonomic knowledge and very few taxonomic specialists [107]. Nevertheless, experts argue that soil biodiversity research is now changing, and awareness is growing among scientists and policy makers of the importance of soil biodiversity for the supply of ecosystem goods and services to the human society [108]. However, there is some criticism about the services approach. This issue has been critically reviewed in several papers e.g., [109,110].

There is general consensus that biodiversity loss reduces most ecosystem functions and impairs their stability over time $[24,108]$. However, our understanding of the functional consequences of belowground biodiversity loss is much less developed than that of aboveground biodiversity [111]. Among soil biota, soil fauna has a significant role in soil functioning, in particular in the process of formation of stable soil aggregates, decomposition of organic matter, and population stability of the various soil inhabiting organisms [112]. These invertebrates are classified into meso- and macrofauna according to their body width. Mesofauna are invertebrates with body diameter between 0.1 and $2 \mathrm{~mm}$, dominated by mites (Acari) and springtails (Collembola), with both having an important role in soil organic matter cycling through their feeding activities [100,101]. Macrofauna include invertebrates with body diameter greater than $2 \mathrm{~mm}$, such as earthworms, ants, termites, and beetles, and are important in both organic matter cycling and soil structure formation as ecosystem engineers [24]. All soil fauna is located in a strategic position in the continuum of structures and processes that link basic microbial processes carried out by their colonies and biofilms to the scale of fields and landscapes where ecosystem services are produced [24]. They interact with other soil organisms to form self-organized systems that regulate the fluxes of different ecosystem services [24]. Moreover, in the last two decades soil biodiversity research has revealed that belowground communities have a major role in shaping aboveground biodiversity and the functioning of terrestrial ecosystems [111]. Improving activity and species diversity of soil fauna and flora is therefore essential for restoring and improving soil quality and reducing risks of soil degradation [1]. Ensuring that the biological system is resilient under an uncertain future requires that soil biological diversity be restored as well [97].

\section{Soil Fauna in the Pampas Agroecosystems: The Current State of Knowledge}

We performed a bibliographic analysis of papers published in scientific journals dealing with the impact of different agricultural managements on soil meso- and macrofauna in the Pampas region (Tables 2 and 3). In summary, these studies have still not reached a conclusive stage. Indeed, fairly different results have been found, and this is mainly because the effect of agricultural practices on organisms is not a linear but a complex response, since many factors are involved in how soil communities respond to agricultural practices. Even under the same conditions, responses may vary when different organisms are involved; and when different taxonomic levels are considered, or when different parameters are assessed, responses may also be different because parameters differ in sensitivity to some conditions, such as abundance and species richness. 
Table 2. Summary of the main results obtained in papers published in scientific journals addressing the impact of different agricultural management systems on soil macrofauna in the Pampas region. The papers are presented in chronological order.

\begin{tabular}{|c|c|c|c|}
\hline Citation & Agricultural Systems & Faunal Group & Main Results \\
\hline López et al. [113] & $\begin{array}{l}\text { NA, organic livestock, intensive } \\
\text { fertilization livestock and CT. }\end{array}$ & Enchytraeids. & No clear pattern according to management systems. \\
\hline Lietti et al. [114] & $\begin{array}{l}\mathrm{CT} \text { and NT with soybean, maize } \\
\text { and fallow. }\end{array}$ & Macrofauna, trophic groups, Carabidae. & $\begin{array}{l}\text { Phytophagous-detritivorous, predaceous arthropods and spiders more } \\
\text { abundant in NT. Higher predator activity in CT. Higher spider frequency in } \\
\text { NT. No difference in carabid density but greater activity under CT. }\end{array}$ \\
\hline Gizzi et al. [115] & $\begin{array}{l}\text { Combination of CT and NT with } \\
\text { different } \% \text { of pasture and agriculture, } \\
\text { and four N fertilization rates. }\end{array}$ & Macrofauna. & $\begin{array}{l}\text { Higher abundances of macrofauna at the time of pasture in the rotation and } \\
\text { in NT than in CT (in one of the sampling years). } \\
\text { No differences between different fertilization treatments. }\end{array}$ \\
\hline Duhour et al. [116] & $\begin{array}{l}\text { NA and three agricultural systems in } \\
\text { a gradient of years of cultivation and } \\
\text { frequency of annual crops. }\end{array}$ & Earthworms (species level). & $\begin{array}{l}\text { Highest abundance in the least disturbed agricultural site. } \\
\text { Highest richness in NA and lowest in the most disturbed agricultural site. }\end{array}$ \\
\hline Domínguez et al. [77] & NA and NT. & $\begin{array}{l}\text { Macrofauna, high range taxa and } \\
\text { species level. }\end{array}$ & $\begin{array}{l}\text { Lower richness and diversity in NT. } \\
\text { Low abundance of earthworms, ants, beetles and spiders in NT. }\end{array}$ \\
\hline Manetti et al. [117] & CT and NT. & Macrofauna, high range taxa. & $\begin{array}{l}\text { In general, no differences in abundance. When different, patterns changed } \\
\text { in different sampling times for total macrofauna, earthworms, Chilopoda, } \\
\text { Diplopoda and Enchytraeidae. }\end{array}$ \\
\hline Masín et al. [118] & $\begin{array}{l}\mathrm{CT} \text { and NT with and without added } \\
\text { organic amendments. }\end{array}$ & Earthworms (species level). & $\begin{array}{l}\text { Highest abundance in NT with organic amendments. } \\
\text { Richness: only } 3 \text { species, all exotic species. }\end{array}$ \\
\hline Maitre et al. [119] & $\begin{array}{l}\text { Livestock in woodland, livestock in } \\
\text { grassland, fallow field and NT with and } \\
\text { without added organic amendments. }\end{array}$ & Earthworms. & $\begin{array}{l}\text { Very low abundances in NT without organic amendments. Highest } \\
\text { abundances in NT with organic amendments. }\end{array}$ \\
\hline Díaz Porres et al. [120] & $\mathrm{NA}, \mathrm{CT}$ and livestock. & $\begin{array}{l}\text { Macrofauna, high range taxa (Order), in } \\
\text { some cases, Family. }\end{array}$ & $\begin{array}{l}\text { Total density and richness were higher in NA than in CT, with livestock } \\
\text { showing intermediate values. }\end{array}$ \\
\hline Domínguez et al. [102] & $\begin{array}{l}\mathrm{NA}, \mathrm{CT} \text { and NT in conventional farming; } \\
\text { organic farming with tillage (ORG). }\end{array}$ & Macrofauna, earthworms. & $\begin{array}{l}\text { Higher macrofauna abundances in ORG than in both CT and NT. No } \\
\text { differences between CT and NT. } \\
\text { Earthworms absent in NT and more abundant in ORG than in CT. }\end{array}$ \\
\hline Falco et al. [121] & $\begin{array}{l}\text { NA, recent agricultural sites ( } 2 \text { years), } \\
\text { agricultural sites with } 50 \text { years of } \\
\text { continuous intensive agriculture, } \\
\text { currently under NT. }\end{array}$ & Earthworms (species level). & $\begin{array}{l}\text { Highest earthworm abundance in the highest soil use intensity. Earthworm } \\
\text { community dominated by exotic species (mainly Aporrectodea spp.). }\end{array}$ \\
\hline Domínguez and Bedano [78] & NA, NT and RT. & $\begin{array}{l}\text { Macrofauna, high range taxa; species for } \\
\text { earthworms, beetles and ants. }\end{array}$ & $\begin{array}{l}\text { Lower abundance of earthworms, ants, beetles and spiders in agriculture } \\
\text { than in NA. } \\
\text { More spiders in NT than in RT, and the opposite for ants and potworms. } \\
\text { Profound changes in species composition of ants and beetles in both NT } \\
\text { and RT compared to NA. }\end{array}$ \\
\hline
\end{tabular}


Table 2. Cont

\begin{tabular}{|c|c|c|c|}
\hline Citation & Agricultural Systems & Faunal Group & Main Results \\
\hline Domínguez and Bedano [68] & NA, organic farming, $\mathrm{CT}$ and NT. & $\begin{array}{l}\text { Earthworms (species level) } \\
\text { and enchytraeids. }\end{array}$ & $\begin{array}{l}\text { Decrease in earthworm richness from } 5 \text { in NA to } 2 \text { in ORG and } 1 \text { in NT and } \\
\text { CT. Highest abundance in NA, followed by ORG. } \\
\text { Enchytraeid abundance according to the gradient NT }>\mathrm{ORG}>\mathrm{PT}>\mathrm{GR} \text {. }\end{array}$ \\
\hline Bedano et al. [122] & $\begin{array}{l}\mathrm{NA}, \mathrm{CT} \text {, and two variants of NT: NT } \\
\text { with good agricultural practices (GAPs) } \\
\text { (intensive crop rotation, nutrient } \\
\text { replacement, and minimized } \\
\text { agrochemical use) and NT without GAPs } \\
\text { (No-GAP) (soybean monoculture, low } \\
\text { nutrient replacement and high } \\
\text { agrochemical use). }\end{array}$ & Macrofauna, high range taxa. & $\begin{array}{l}\text { Earthworms more abundant in NA. No differences between GAP } \\
\text { and No-GAP. } \\
\text { Ant abundance according to the gradient: NA }>\text { GAP }>\text { No-GAP = CT. } \\
\text { Soil and litter beetle abundance according to the gradient: } \\
\text { NA }>\text { GAP = No-GAP }>\text { CT. }\end{array}$ \\
\hline Marasas et al. [123] & NT and CT. & $\begin{array}{l}\text { Pitfall study: Beetles (total) and } \\
\text { Carabidae (species). }\end{array}$ & Higher abundance and higher diversity of Carabidae in NT than in CT. \\
\hline Marasas et al. [124] & $\begin{array}{l}\text { NT, CT and a field boundary without } \\
\text { agricultural use. }\end{array}$ & $\begin{array}{l}\text { Pitfall study: Macrofauna, } \\
\text { trophic groups. }\end{array}$ & $\begin{array}{l}\text { Predators more abundant, detritivores slightly more abundant and } \\
\text { similarly abundant phytophages in NT compare to CT. }\end{array}$ \\
\hline Manetti et al. [125] & $\begin{array}{l}\mathrm{CT} \text { and NT during three } \\
\text { cropping seasons. }\end{array}$ & $\begin{array}{l}\text { Pitfall study: Macrofauna, high } \\
\text { range taxa. }\end{array}$ & Total macrofauna more abundant in NT than in CT for some cycles. \\
\hline
\end{tabular}

Table 3. Summary of the main results obtained in papers published in scientific journals addressing the impact of different agricultural management systems on soil mesofauna in the Pampas region. The papers are presented in chronological order.

\begin{tabular}{llll}
\hline Citation & Agricultural systems & Faunal group & Main results \\
\hline Pilatti et al. [126] & $\begin{array}{l}\text { NA, a mixed system (cattle and conventional agriculture), continuos } \\
\text { agriculture for 15 years with vertical tillage, and continuos agriculture for } \\
\text { 30 years with plough tillage. }\end{array}$ & Total mesofauna. & Reduction of abundances following the management intensity gradient. \\
\hline Gómez et al. [127] & $\begin{array}{l}\text { Chemical fallow (NT); mechanical fallow with vertical tillage; intensive } \\
\text { mechanical fallow with vertical tillage and mouldboard plough. }\end{array}$ & Total mesofauna. & No differences in mesofauna among treatments. \\
\hline Bedano et al. [100] & Gradient of increasing land use intensity: NA, cattle, mixed and agricultural. & $\begin{array}{l}\text { Total Acari and Acari, } \\
\text { high range taxa. }\end{array}$ & $\begin{array}{l}\text { Reduction of abundances of oribatid, mesostigmatid and total mites } \\
\text { following the gradient. }\end{array}$ \\
\hline Bedano et al. [101] & Gradient of increasing land use intensity: NA, cattle, mixed and agricultural. & $\begin{array}{l}\text { Collembola, Symphyla } \\
\text { and Pauropoda. }\end{array}$ & Lower density of collembolans and pauropods in agricultural system. \\
\hline Bedano \& Ruf [128] & Gradient of increasing land use intensity: NA, cattle, mixed and agricultural. & Gamasina species. & $\begin{array}{l}\text { Reduction of abundance and richness of Gamasina following the gradient } \\
\text { of land use intensity. }\end{array}$ \\
\hline Ferraro \& Ghersa [129] & $\begin{array}{l}\text { Cropping management variables were summarized by means of descriptors } \\
\text { of pesticide use and tillage intensity, among others }\end{array}$ & $\begin{array}{l}\text { Acari, Collembola. } \\
\text { number of pesticides used. } \\
\text { Higher mite density with less tillage impact. }\end{array}$ \\
\hline Gizzi et al. [115] & $\begin{array}{l}\text { Combination of CT and NT with different } \% \text { of pasture and agriculture, and } \\
\text { four N fertilization rates. }\end{array}$ & Total mesofauna. & $\begin{array}{l}\text { Higher abundances in implanted pastures than in agriculture, in one of } \\
\text { the sampling years. }\end{array}$ \\
\hline
\end{tabular}


Table 3. Cont

\begin{tabular}{llll}
\hline Citation & Agricultural systems & Faunal group & Main results \\
\hline Arolfo et al. [76] & NA and NT. & $\begin{array}{l}\text { Total Acari and, high } \\
\text { range taxa. }\end{array}$ & $\begin{array}{l}\text { Higher abundances in NA in both litter and soil layer. } \\
\text { Oribatid and mesostigmatid associated with NA. } \\
\text { Prostigmata and Astigmata associated with NT. }\end{array}$ \\
\hline Bedano et al. [130] & $\begin{array}{l}\text { 10 arable sites (NT, RT and CT) compared with three benchmark systems: } \\
\text { NA, cattle-raising (CA), and mixed production system (MI) (cattle raising } \\
\text { and agriculture). }\end{array}$ & High range taxa of Acari. & $\begin{array}{l}\text { Most arable sites were below the conservative threshold of the } \\
\text { 25th percentile of the NA and CA benchmarks, which were similar to } \\
\text { each other. }\end{array}$ \\
\hline Sandler et al. [131] & NA, NT and cattle grazing. & Collembola (Families). & $\begin{array}{l}\text { Diversity and abundance increased together with the increase in land use } \\
\text { intensity. The response varied with Collembola families. }\end{array}$ \\
\hline Domínguez et al. [102] & $\begin{array}{l}\text { NA, CT and NT in conventional farming, organic farming with } \\
\text { tillage (ORG). }\end{array}$ & Mesofauna, Collembola. & $\begin{array}{l}\text { Total mesofauna abundance following the gradient: GR = ORG }>\text { NT = CT. } \\
\text { Collembola abundances following the gradient: GR = ORG = NT }>\text { CT. }\end{array}$ \\
\hline & $\begin{array}{l}\text { NA, CT, and two variants of NT: NT with good agricultural practices (GAPs) } \\
\text { (intensive crop rotation, nutrient replacement, and minimized agrochemical } \\
\text { use) and NT without GAPs (No-GAP) (soybean monoculture, low nutrient } \\
\text { replacement and high agrochemical use). }\end{array}$ & $\begin{array}{l}\text { Litter oribatid and prostigmatid mites more abundant following } \\
\text { the gradient. } \\
\text { Soil oribatids with no differences between GAP and No-GAP. } \\
\text { Litter mesostigmatid followed the gradient: NA }>\text { GAP }>\text { CT }>\text { No-GAP, } \\
\text { whereas soil mesostigmatids were more abundant in NA followed } \\
\text { by No-GAP. } \\
\text { Litter collembolans and soil prostigmatids followed } \\
\text { NA2] }>\text { GAP }>\text { No-GAP = CT. Soil collembolans more abundant in NA. }\end{array}$ \\
\hline
\end{tabular}


Another factor that makes it difficult to obtain general and conclusive results is the variety of practices involved in the main types of agricultural systems. Thus, it is essential (but difficult) to consider the specific practices performed by each farmer in order to understand soil biota responses.

Regarding studies which deal with macrofauna (Table 2), we have indicated those which compare surface community in NT versus CT (pitfall studies). This can be considered a rather partial approach to compare both systems, since they are opposite in terms of plant residue management, with CT burying residues and NT keeping them on the soil surface. In fact, pitfall studies here reviewed do not provide conclusive results, even when several taxa of litter dwellers are positively affected by a higher cover in NT, as expected. In Table 3 we summarize the results from all the papers studying the response of soil mesofauna to different agricultural management in the Pampas region. The value of mesofauna as indicator of perturbations in the soil environment has also been corroborated in several works. However, in the Argentine Pampas, this group has been less studied than macrofauna.

This review of papers highlights several aspects. The first one is the very scarce information available about agricultural management practices not belonging to the conventional or industrial systems (organic, agroecological, biodynamic), in extensive cropping schemes. Regarding macrofauna, to the best of our knowledge, only two papers studied how organic management practices affect macrofauna community [68,102], and both suggest that large-scale organic agriculture shows a less negative impact than the conventional systems. Another remarkable aspect arising from this review is that there are no conclusive results about the expected benefits on soil biota of NT compared to RT or CT, and that they are taxa-dependent. There is only one study showing that among NT systems, the use of GAPs has a positive effect on soil fauna. A more general conclusion is that all agricultural soils are being strongly modified in biological aspects comparing to the same soils without management interventions, although the studied unmanaged systems (natural or semi-natural soils) are boundaries or abandoned pastures often of small size, which may lead to an underestimation of soil fauna communities inhabiting these reference soils. It is also important to highlight that most of the reviewed studies were conducted with a rather coarse taxonomic resolution (Order, Family), and that a more detailed taxonomic work would be more useful to understand the changes in soil fauna. For example it has been suggested that Gamasina species data provide a clearer separation of managements than the family data [132]. The family approach may only be suitable to elucidate the influence of great geographical differences or also of certain land uses (e.g., grasslands from forests and arable sites) [132].

\section{Conclusions and Outlook}

The reviewed papers dealing with the response of soil fauna to a wide range of land use types and agricultural managements reveals some significant outcomes. The extensive agricultural organic systems are very poorly studied in the Pampas, especially in terms of soil fauna. Two available studies suggest that large-scale organic farming has a better environmental performance than the conventional systems. However, there is also a lack of information on how the benefits of organic farming on soil biota are transferred to benefits in soil process, such as nutrient cycling and soil structure formation, and thus in soil fertility and crop productivity maintenance. This hinders the promotion of organic agriculture among producers and decision makers. Globally, a very important question remains unclear: how are changes in agricultural soil biota community in agricultural systems affecting the ability of Pampas soils to perform soil ecosystem processes and thus sustain long time crop productivity? No-till has been proposed as a conservative management system, which relies on soil fauna activity for a better functioning. However, results from the Pampas region do not support this idea. In the available studies, there are not clear evidences about the benefits of NT compared to $\mathrm{RT}$ or CT in terms of soil fauna.

Challenges regarding agricultural sustainability are within a complex context, and there are important constraints for adopting alternatives to current practices, which are also environmentally conflicting. Since in Argentina most land is managed by commercial farmers owning or leasing large 
and medium-size farms that respond to market forces, the adoption of alternative management systems is only possible if they ensure an equivalent economic return or if there are strong public policies promoting them. For example, in the case of conventional agriculture, there are growing evidences about the positive impacts of increasing crop rotation and incorporating winter cover crops [41]. However, these practices are not massively applied because they require high economic investments.

Several studies conducted worldwide prove organic farming to perform better than conventional farming in improving soil quality in terms of both biophysical and ecological properties [133-136]. However, as these authors pointed out, local characteristics deserve attention and agricultural practices should be adopted with much concern for specific local features. As described earlier, agriculture in the Pampas is rather different from practices applied in Europe, where most of the literature is generated. Therefore, even when there are some data suggesting a better environmental performance, the adoption of large-scale organic agriculture in the Pampas has to face other constraints. One of them is the economic constraint, an issue that is being strongly debated in other organic systems in the world at present $[75,137]$ but largely understudied for Pampa's large-scale organic farming. On the other hand, the complexity involved in adopting organic production, including the necessary knowledge, in contrast to the simplicity of introducing conventional agricultural packages, is also very relevant; that is where public policies should be applied. The challenge of sustainability needs a multi-criteria approach, to which our analysis contributes mainly from the environmental perspective; additional social, economic and cultural aspects of these challenges should be addressed to complement our contribution. Therefore, we identify a need to study these systems from an integrated approach, including all aspects of sustainability.

In both conventional and organic paradigms, management strategies tending to improve soil biological conditions would provide an improvement of soil quality and the whole system environmental sustainability. The protection of soil as a resource implies the protection of its biodiversity as the engine that moves several processes basic for ecosystem functioning and finally for crop production. Therefore, towards reconciling agricultural production with the conservation of the enormous natural capital that is the soil, it is necessary to design the future agricultural systems paying close attention to soil fauna: i.e., to implement agricultural and livestock management systems that promote the development of an abundant, diverse and active soil fauna, under the paradigm of either conventional or organic agriculture.

Acknowledgments: We are grateful to Tiziano Gomiero for his invitation to contribute to this special issue and for the useful comments on a previous draft. This study was funded by the project PICT 0320/08 of the Argentinean National Agency for Scientific and Technological Promotion (ANPCyT), project PAE 36976-PID52 by the ANPCyT, the MINCyT Córdoba and the SECyT (National University of Río Cuarto). A. Domínguez and J.C. Bedano are members of the Argentinean National Council for Scientific and Technical Research (CONICET). J. Brasca corrected the English.

Author Contributions: Both authors contributed equally to this paper. They both conceived, designed and wrote the whole review based on invitation from the Guest Editor.

Conflicts of Interest: The authors declare no conflict of interest.

\section{References}

1. Lal, R. Restoring soil quality to mitigate soil degradation. Sustainability 2015, 7, 5875-5895. [CrossRef]

2. Wall, D.H.; Six, J. Give soils their due. Science 2015, 347, 695. [CrossRef] [PubMed]

3. McNeill, J.R.; Winiwarter, V. Breaking the sod: Humankind, history, and soil. Science 2004, 304, 1627-1629. [CrossRef] [PubMed]

4. Minami, K. Soil and humanity: Culture, civilization, livelihood and health. Soil Sci. Plant. Nutr. 2009, 55, 603-615. [CrossRef]

5. Chang-Qun, D.; Xue-Chun, G.; Wang, J.; Chien, P.K. Relocation of civilization centers in ancient China: Environmental factors. Ambio 1998, 27, 572-575. 
6. Pimentel, D.; Harvey, C.; Resosudarmo, P.; Sinclair, K.; Kurz, D.; McNair, M.; Crist, S.; Shpritz, L.; Fitton, L.; Saffouri, R.; et al. Environmental and economic costs of soil erosion and conservation benefits. Science 1995, 267, 1117-1123. [CrossRef] [PubMed]

7. Agriculture at a Crossroads: International Assessment of Agricultural Knowledge, Science and Technology for Development. Available online: http://www.unep.org/dewa/agassessment/reports/IAASTD/EN/ Agriculture\%20at\%20a\%20Crossroads_Global\%20Report\%20(English).pdf (accessed on 10 March 2016).

8. Foley, J.; DeFries, R.; Asner, G.; Barford, C.; Bonan, G.; Carpenter, S.; Chapin, F.; Coe, M.; Daily, G.; Gibbs, H.; et al. Global consequences of land use. Science 2005, 309, 570-574. [CrossRef] [PubMed]

9. Gomiero, T.; Pimentel, D.; Paoletti, M. Is there a need for a more sustainable agriculture? Crit. Rev. Plant. Sci. 2011, 30, 6-23. [CrossRef]

10. Foley, J.; Ramankutty, N.; Brauman, K.; Cassidy, E.; Gerber, J.; Johnston, M.; Mueller, N.; O'Connell, C.; Ray, D.K.; West, P.W.; et al. Solutions for a cultivated planet. Nature 2011, 478, 337-342. [CrossRef] [PubMed]

11. Royal Society. Reaping the Benefits: Science and the Sustainable Intensification of Global Agriculture. 2009. Available online: https://royalsociety.org/ /media/Royal_Society_Content/policy/publications/2009/ 4294967719.pdf (accessed on 10 March 2016).

12. World Population Prospects: The 2015 Revision, Key Findings and Advance Tables. Available online: https: //esa.un.org/unpd/wpp/publications/files/key_findings_wpp_2015.pdf (accessed on 10 March 2016).

13. Tomlinson, I. Doubling food production to feed the 9 billion: A critical perspective on a key discourse of food security in the UK. J. Rural Stud. 2013, 29, 81-90. [CrossRef]

14. Tscharntke, T.; Clough, Y.; Wanger, T.C.; Jackson, L.; Motzke, I.; Perfecto, I.; Vandermeer, J.; Whitbread, A. Global food security, biodiversity conservation and the future of agricultural intensification. Biol. Conserv. 2012, 151, 53-59. [CrossRef]

15. Perfecto, I.; Vandermeer, J. Separación o integración para la conservación de biodiversidad: La ideología detrás del debate land-sharing frente a land-sparing. Ecosistemas 2012, 21, 1-2. (In Spanish)

16. FAO. The State of Food Insecurity in the World 2009: Economic Crises-Impacts and Lessons Learned. Available online: http://www.fao.org/docrep/012/i0876e/i0876e00.htm (accessed on 10 April 2016).

17. Agriculture at a Crossroads, Latin America and the Caribbean (LAC) Report. Available online: http://www.unep.org/dewa/agassessment/reports/subglobal/Agriculture_at_a_Crossroads_Volume_ III_Latin_America_and_the_Caribbean_Subglobal_Report.pdf (accessed on 10 March 2016).

18. Chappell, M.J.; LaValle, L.A. Food security and biodiversity: Can we have both? An agroecological analysis. Agric. Hum. Values 2011, 28, 3-26. [CrossRef]

19. Feeding the World-A Look at Biotechnology \& World Hunger (2). Available online: http:/ / www.pewtrusts.org/en/research-and-analysis/reports/2004/03/03/feeding-the-world-a-look-atbiotechnology-and-world-hunger(2) (accessed on 10 March 2016).

20. FAO. The State of Food and Agriculture 2010-2011. Available online: http://www.fao.org/docrep/013/ i2050e/i2050e.pdf (accessed on 10 March 2016).

21. Eswaran, H.; Lal, R.; Reich, P.F. Land degradation: An overview. Available online: http://www.nrcs.usda. gov/wps/portal/nrcs/detail/soils/use/?cid=nrcs142p2_054028 (accessed on 10 March 2016).

22. FAO. Nothing Dirty here: FAO Kicks off International Year of Soils, 2015. Available online: http://www.fao. org/news/story/en/item/270812/icode/ (accessed on 10 March 2016).

23. Bennett, E.M.; Peterson, G.D.; Gordon, L.J. Understanding relationships among multiple ecosystem services. Ecol. Lett. 2009, 12, 1-11. [CrossRef] [PubMed]

24. Lavelle, P.; Decaëns, T.; Aubert, M.; Barot, S.; Blouin, M.; Bureau, F.; Margerie, P.; Mora, P.; Rossi, J.P. Soil invertebrates and ecosystem services. Eur. J. Soil Biol. 2006, 42, S3-S15. [CrossRef]

25. Barrios, E. Soil biota, ecosystem services and land productivity. Ecol. Econ. 2007, 64, 269-285. [CrossRef]

26. Tsiafouli, M.A.; Thébault, E.; Sgardelis, S.P.; de Ruiter, P.C.; van der Putten, W.H.; Birkhofer, K.; Hemerik, L.; de Vries, F.T.; Bardgett, R.T.; Brady, M.V.; et al. Intensive agriculture reduces soil biodiversity across Europe. Glob. Chang. Biol. 2015, 21, 973-985. [CrossRef] [PubMed]

27. FAOSTAT. Available online: http:// faostat.fao.org (accessed on 10 December 2015).

28. Viglizzo, E.; Lertora, F.; Pordomingo, A.; Bernardos, J.; Roberto, Z.; del valle, H. Ecological lessons and applications from one century of low external-input farming in the pampas of Argentina. Agric. Ecosyst. Environ. 2001, 83, 65-81. [CrossRef] 
29. Manuel-Navarrete, D.; Gallopin, G.C.; Blanco, M.; Díaz-Zorita, M.; Ferraro, D.; Herzer, H.; Laterra, P.; Murmis, M.; Podesta, G.; Rabinovich, J.; et al. Multi-causal and integrated assessment of sustainability: The case of agriculturization in the Argentine Pampas. Environ. Dev. Sustain. 2009, 11, 621-638. [CrossRef]

30. Solbrig, O.T.; Viglizzo, E. Sustainable Farming in the Argentine Pampas: History, Society, Economy, and Ecology; DRCLAS Working Paper No 99/00-1; Harvard University Press: Cambridge, MA, USA, 1998.

31. Burkart, R.; Bárbaro, N.; Sánchez, R.; Gómez, D. Ecorregiones de Argentina; Editorial APN Pub: Buenos Aires, Argentina, 1999. (In Spanish)

32. Solbrig, O.T. Towards a Sustainable Pampa Agriculture: Past Performance and Prospective Analysis; DRCLAS Working Paper No 96/97-6; Harvard University Press: Cambridge, MA, USA, 1998.

33. Trigo, E.J.; Cap, E.J. The impact of the introduction of transgenic crops in Argentinean agriculture. AgBioForum 2004, 6, 87-94.

34. Qaim, M.; Traxler, G. Roundup ready soybeans in Argentina: Farm level and aggregate welfare effects. Agric. Econ. 2005, 32, 73-86. [CrossRef]

35. Cáceres, D.M. Accumulation by dispossession and socio-environmental conflicts caused by the expansion of agribusiness in Argentina. J. Agrar. Chang. 2014, 15, 116-147. [CrossRef]

36. El Nuevo Escenario de la Ganadería en Argentina. Available online: http://www.bcr.com.ar/Secretara\% 20de\%20Cultura/Revista\%20Institucional/2011/Agosto/GANADERIA.pdf (accessed on 10 March 2016). (In Spanish)

37. SENASA. Establecimientos de Engorde a Corral. Available online: http://www.senasa.gov.ar/sites/ default/files/ARBOL_SENASA/INFORMACION/INFORMES\%20Y\%20ESTADISTICAS/Informes $\%$ 20y\%20estadisticas\%20Animal/BOVINOS/BOVINOS/INFORMES\%20ESTADISTICOS/Corral\%20junio_ 2013.pdf (accessed on 10 March 2016). (In Spanish)

38. Ten Years of Genetically Modified Crops in Argentine Agriculture. Available online: http://argenbio.org/ biblioteca/Ten_Years_of_GM_Crops_in_Argentine_Agriculture_02_01_07.pdf (accessed on 10 March 2016).

39. FAO. What is Conservation Agriculture? Available online: http://www.fao.org/ag/ca/1a.html (accessed on 15 September 2015).

40. CESO-Centro de Estudios Económicos y Sociales Scalabrini Ortiz. Costos y Rentabilidad del Cultivo de Soja en la Argentina. Available online: http:/ /www.ceso.com.ar/ (accessed on 10 March 2016). (In Spanish).

41. Wingeyer, A.B.; Amado, T.J.; Pérez-Bidegain, M.; Studdert, G.A.; Varela, C.H.; Garcia, F.; Karlen, D.L. Soil quality impacts of current South American agricultural practices. Sustainability 2015, 7, 2213-2242. [CrossRef]

42. SAGPyA. Censo Nacional Agropecuario 2002, National Institute of Statistics and Census of Argentina. Available online: http:/ / www.indec.mecon.gov.ar/agropecuario/cna.asp (accessed on 10 October 2015). (In Spanish)

43. Chappell, M.J.; Wittman, H.; Bacon, C.; Ferguson, B.; Barrios, L.; Barrios, R.; Jaffee, D.; Lima, J.; Méndez, E.; Morales, H.; et al. Food sovereignty: An alternative paradigm for poverty reduction and biodiversity conservation in Latin America. F1000Research 2013, 2, 235. [CrossRef] [PubMed]

44. Urcola, H.A.; de Sartre, X.A.; Veiga, I.; Elverdin, J.; Albaladejo, C. Land tenancy, soybean, actors and transformations in the Pampas: A district balance. J. Rural Stud. 2015, 39, 32-40. [CrossRef]

45. Caligaris, G. Concentración y centralización del capital agrario en la región pampeana. El caso de los grandes pooles de siembra. Mundo Agrario. 2015, 16, 31. (In Spanish)

46. Infocampo. Altos Precios de Alquiler de Campos en Argentina Ecuación Para Campaña 2014/15. Available online: http://infocampo.com.ar/nota/campo/61010/altospreciosdealquilerdecamposenargentina complicanecuacionparacampana201415 (accessed on 10 March 2016). (In Spanish)

47. Infocampo. Arrendamientos: Afirman que la Caída en los Precios a la Producción. Available online: http://infocampo.com.ar/nota/campo/44379/arrendamientosafirmanquelacaidaenlospreciosbeneficiaraala produccion (accessed on 10 March 2016). (In Spanish)

48. Arora, P.; Bert, F.; Podestac, G.; Krantz, D.H. Ownership effect in the wild: Influence of landownership on agribusiness goals and decisions in the Argentine Pampas. J. Behav. Exp. Econ. 2015, 58, 162-170. [CrossRef]

49. Manuel-Navarrete, D.; Gallopín, G.C. Feeding the world sustainably: Knowledge governance and sustainable agriculture in the Argentine Pampas. Environ. Dev. Sustain. 2012, 14, 321-333. [CrossRef]

50. Diffusion Process in Networks: The Case of Transgenic Soybean in Argentina. Available online: http: / / www.littec.ungs.edu.ar/pdfingles/BisangGlobellicsEnglish.pdf (accessed on 10 March 2016). 
51. SIIA. Sistema Integrado de Información Agropecuaria. Available online: http://www.siia.gov.ar/_apps/ siia/arbol/total_pciaX.php?respuesta=AG (accessed on 10 March 2016). (In Spanish)

52. International Agency for Research on Cancer Volume 112: Some Organophosphate Insecticides and Herbicides. Available online: https://www.iarc.fr/en/media-centre/iarcnews/pdf/MonographVolume112. pdf (accessed on 10 March 2016).

53. Buch, A.C.; Brown, G.G.; Niva, C.C.; Sautter, K.D.; Sousa, J.P. Toxicity of three pesticides commonly used in Brazil to Pontoscolex corethrurus (Müller, 1857) and Eisenia andrei (Bouché, 1972). Appl. Soil Ecol. 2013, 69, 32-38. [CrossRef]

54. Casabé, N.; Piola, L.; Fuchs, J.; Oneto, M.L.; Pamparato, L.; Basack, S.; Giménez, R.; Massaro, R.; Papa, J.C.; Kesten, E. Ecotoxicological assessment of the effects of glyphosate and chlorpyrifos in an Argentine soya field. J. Soils Sediments 2007, 7, 232-239. [CrossRef]

55. Correia, F.V.; Moreira, J.C. Effects of glyphosate and 2, 4-D on earthworms (Eisenia. foetida) in laboratory tests. Bull. Environ. Contam. Toxicol. 2010, 85, 264-268. [CrossRef] [PubMed]

56. Dalby, P.R.; Baker, G.H.; Smith, S.E. Glyphosate, 2, 4-db and dimethoate: Effects on earthworm survival and growth. Soil Biol. Biochem. 1995, 27, 1661-1662. [CrossRef]

57. Santos, M.J.G.; Morgado, R.; Ferreira, N.G.C.; Soares, A.M.V.M.; Loureiro, S. Evaluation of the joint effect of glyphosate and dimethoate using a small-scale terrestrial ecosystem. Ecotox. Environ. Safe 2011, 74, 1994-2001. [CrossRef] [PubMed]

58. Santos, M.J.G.; Ferreira, M.F.L.; Cachada, A.; Duarte, A.C.; Sousa, J.P. Pesticide application to agricultural fields: Effects on the reproduction and avoidance behaviour of Folsomia candida and Eisenia andrei. Ecotoxicology 2012, 21, 2113-2122. [CrossRef] [PubMed]

59. Yasmin, S.; D'Souza, D. Effect of pesticides on the reproductive output of Eisenia fetida. Bull. Environ. Contam. Toxicol. 2007, 79, 529-532. [CrossRef] [PubMed]

60. García-Torres, T.; Giuffré, L.; Romaniuk, R.; Ríos, R.P.; Pagano, E.A. Exposure assessment to glyphosate of two species of annelids. Bull. Environ. Contam. Toxicol. 2014, 93, 209-214. [CrossRef] [PubMed]

61. Piola, L.; Fuchs, J.; Oneto, M.L.; Basack, S.; Kesten, E.; Casabé, N. Comparative toxicity of two glyphosate-based formulations to Eisenia andrei under laboratory conditions. Chemosphere 2013, 91, 545-551. [CrossRef] [PubMed]

62. Zhou, C.F.; Wang, Y.J.; Li, C.C.; Sun, R.J.; Yo, Y.C.; Zhou, D.M. Subacute toxicity of copper and glyphosate and their interaction to earthworm (Eisenia fetida). Environ. Pollut. 2013, 180, 71-77. [CrossRef] [PubMed]

63. Santadino, M.; Coviella, C.; Momo, F. Glyphosate sublethal effects on the population dynamics of the earthworm Eisenia. fetida (Savigny, 1826). Water Air Soil Pollut. 2014, 225, 1-8. [CrossRef]

64. Domínguez, A.; Brown, G.G.; Sautter, K.D.; Ribas de Oliveira, C.M.; Carvalho de Vasconcelos, E.; Niva, C.C.; Bartz, M.L.C.; Bedano, J.C. Toxicity of AMPA to the earthworm Eisenia andrei Bouché, 1972 in tropical artificial soil. Sci. Rep. 2016, 6, 19731. [CrossRef] [PubMed]

65. Díaz-Zorita, M.; Duarte, G.; Grove, J.H. A review of no-till systems and soil management for sustainable crop production in the subhumid and semiarid Pampas of Argentina. Soil Tillage Res. 2002, 65, 1-18. [CrossRef]

66. Taboada, M.A.; Micucci, F.G.; Cosentino, D.J.; Lavado, R.S. Comparison of compaction induced by conventional and zero tillage in two soil of the Rolling Pampa of Argentina. Soil Tillage Res. 1998, 49, 57-63. [CrossRef]

67. Buschiazzo, D.E.; Panigatti, J.L.; Unger, P.W. Tillage effects on soil properties and crop production in the subhumid and semiarid Argentinean Pampas. Soil Tillage Res. 1998, 49, 105-116. [CrossRef]

68. Domínguez, A.; Bedano, J.C. Earthworm and enchytraeid co-occurrence pattern in organic and conventional farming: consequences for ecosystem engineering. Soil Sci. 2016, 181, 148-156. [CrossRef]

69. Pittelkow, C.M.; Liang, X.; Linquist, B. Productivity limits and potentials of the principles of conservation agriculture. Nature 2015, 517, 365-368. [CrossRef] [PubMed]

70. Hobbs, P.R.; Sayre, K.; Gupta, R. The role of conservation agriculture in sustainable agriculture. Phil. Trans. R. Soc. B 2008, 363, 543-555. [CrossRef] [PubMed]

71. Cantú, M.; Becker, A.; Bedano, J.C.; Schiavo, H. Evaluación de la calidad de suelos mediante el uso de indicadores e índices. Ci Suelo 2007, 25, 173-178. (In Spanish)

72. Cantú, M.; Becker, A.; Bedano, J.C.; Schiavo, H. Indicadores e índices de degradación de suelos en la región central templada húmeda de Argentina. In Proceedings of the XV Congreso Latinoamericano de Ciencia del Suelo and V Congreso Cubano de la Ciencia del Suelo, Varadero, Cuba, 11 November 2001. (In Spanish) 
73. Becker, A.R. Evaluación del Proceso de Degradación de Suelos por Erosion Hídrica en una Subcuenca de la Región Pedemontana del Suroeste de la Provincial de Cordoba, Argentina. Ph.D. Thesis, National University of Río Cuarto, Córdoba, Argentina, 19 October 2006. (In Spanish)

74. Becker, A.R.; Díaz, E.; Cantú, M.P.; Meyers, C.; Cholaky, C. Aplicación del Modelo WEPP en la Predicción de Erosión Hídrica en el Suroeste de Córdoba, Argentina. In Proceedings of the XX Congreso Argentino de la Ciencia del Suelo, Salta, Argentina, 19 Sepetember 2006. (In Spanish)

75. Arolfo, R.V.; Bedano, J.C.; Becker, A.R. El Impacto del Paquete Tecnológico Siembra Directa-soja Transgénica-glisfosato en la Mesofauna del suelo en la Cuenca de Gral. Deheza, Córdoba. In Proceedings of the XXI Congreso Argentino de la Ciencia del Suelo, San Luis, Argentina, 13 May 2008. (In Spanish)

76. Arolfo, R.V.; Bedano, J.C.; Becker, A.R. Efectos del cultivo de soja transgénica en siembra directa sobre la taxocenosis de ácaros edáficos en haplustoles del centro de Córdoba. Ci Suelo 2010, 28, 191-200. (In Spanish)

77. Domínguez, A.; Bedano, J.C.; Becker, A. Negative effects of no-till on soil macrofauna and litter decomposition in Argentina as compared with natural grasslands. Soil Tillage Res. 2010, 110, 51-59. [CrossRef]

78. Domínguez, A.; Bedano, J.C. The adoption of no-till instead of reduced tillage does not improve some soil quality parameters in Argentinean Pampas. Appl. Soil Ecol. 2016, 98, 166-176. [CrossRef]

79. Poisot, A.; Speedy, A.; Kueneman, E. Good agricultural practices-A working concept. In Proceedings of FAO Internal Workshop on Good Agricultural Practices, Rome, Italy, 27-29 October 2004.

80. Albertengo, J.; Belloso, C.; Giraudo, M.; Peiretti, R.; Permingeat, H.; Wall, L. Chapter 15: Conservation agriculture in Argentina. In Conservation Agriculture: Global Prospects and Challenges; Jat, R., Sahrawat, K., Kassam, A., Eds.; CABI: Oxfordshire, UK, 2013; pp. 352-374.

81. Alvarez, R.; Steinbach, H.S. A review of the effects of tillage systems on some soil physical properties, water content, nitrate availability and crops yield in the Argentine Pampas. Soil Tillage Res. 2009, 104, 1-15. [CrossRef]

82. FAO. Conservation Agriculture-Frequently Asked Questions. Available online: www.fao.org/ag/ca/doc/ Y3783e.pdf (accessed on 10 March 2016).

83. Palau, H.; Senesi, S.; Mogni, L.; Ordóñez, I. Impacto Económico Macro y Micro de Malezas Resistentes en el Agro Argentino; ADAMA-FAUBA Pub.: Buenos Aires, Argentina, 2015; p. 68. (In Spanish)

84. Papa, J.C. Malezas Tolerantes y Resistente a Herbicidas; Publicación Miscelánea $\mathrm{N}^{\circ}$ 112: Buenos Aires, Argentina, 2008; pp. 143-149. (In Spanish)

85. Powles, S.B. Review Evolved glyphosate-resistant weeds around the world: Lessons to be learnt. Pest. Manag. Sci. 2008, 64, 360-365. [CrossRef] [PubMed]

86. AAPRESID. Red de Conocimiento de Malezas Resistentes. Available online: http://www.aapresid.org.ar/ rem/ (accessed on 10 March 2016). (In Spanish)

87. Edwards, C.A.; Bohlen, P.J. Biology and Ecology of Earthworms, 3rd ed.; Chapman and Hall: London, UK, 1996.

88. Glyphosate Factsheet. Available online: http://www.mindfully.org/Pesticide/Roundup-GlyphosateFactsheet-Cox.htm (accessed on 10 March 2016).

89. Chan, K.Y. An overview of some tillage impacts on earthworm population abundance and diversity-implications for functioning in soils. Soil Tillage Res. 2001, 57, 179-191. [CrossRef]

90. Sasal, M.C.; Andriulo, A.; Taboada, M.A. Soil porosity characteristics on water dynamics under direct drilling in Argiudolls of the Argentinean Rolling Pampas. Soil Tillage Res. 2006, 87, 9-18. [CrossRef]

91. SENASA. 2014. Available online: http://www.mapo.org.ar/wp-content/uploads/2014/05/informe-senasa2013.pdf (accessed on 12 August 2015). (In Spanish)

92. Lampkin, N. Organic farming: Sustainable agriculture in practice. In The Economics of Organic Farming. An International Perspective; Lampkin, N., Padel, S., Eds.; CABI: Oxford, UK, 1994.

93. Rigby, D.; Cáceres, D. Organic farming and the sustainability of agricultural systems. Agric. Syst. 2001, 68, 21-40. [CrossRef]

94. Van Eekeren, N.; de Boer, H.; Hanegraaf, M.; Bokhorst, J.; Nierop, D.; Bloem, J.; Schoutenf, T.; de Goedeg, R.; Brussaard, L. Ecosystem services in grassland associated with biotic and abiotic soil parameters. Soil Biol. Biochem. 2010, 42, 1491-1504. [CrossRef]

95. Tuck, S.L.; Winqvist, C.; Mota, F.; Ahnström, J.; Turnbull, L.A.; Bengtsson, J. Land-use intensity and the effects of organic farming on biodiversity: A hierarchical meta-analysis. J. Appl. Ecol. 2014, 51, 746-755. [CrossRef] [PubMed] 
96. Pengue, W.A. Agricultura Industrial y Transnacionalizacion en America Latina; GEPAMA-PNUMA: Mexico DF, Mexico, 2005; p. 221. (In Spanish)

97. Scholes, M.C.; Scholes, R.J. Dust unto dust. Science 2013, 342, 565-566. [CrossRef] [PubMed]

98. Aira, M.; McNamara, N.P.; Piearce, T.G.; Domínguez, J. Microbial communities of Lumbricus terrestris L. middens: Structure, activity, and changes through time in relation to earthworm presence. J. Soils Sediments 2009, 9, 54-61. [CrossRef]

99. Bohlen, P.J.; Edwards, C.A.; Zhang, Q.; Parmelee, R.W.; Allen, M. Indirect effects of earthworms on microbial assimilation of labile carbon. Appl. Soil Ecol. 2002, 20, 255-261. [CrossRef]

100. Bedano, J.C.; Cantu, M.P.; Doucet, M.E. Influence of three different land management practices on soil mite (Arachnida: Acari) densities in relation to a natural soil. Appl. Soil Ecol. 2006, 32, 293-304. [CrossRef]

101. Bedano, J.C.; Cantu, M.P.; Doucet, M.E. Soil springtails (Hexapoda: Collembola), symphylans and pauropods (Arthropoda: Myriapoda) under different management systems in agroecosystems of the subhumid Pampa (Argentina). Eur. J. Soil Biol. 2006, 42, 107-119. [CrossRef]

102. Domínguez, A.; Bedano, J.C.; Becker, A.; Arolfo, R. Organic farming fosters agroecosystem functioning in Argentinian temperate soils: Evidence from litter decomposition and soil fauna. Appl. Soil Ecol. 2014, 83, 170-176. [CrossRef]

103. Swift, M.J.; Izac, A.M.N.; van Noordwijk, M. Biodiversity and ecosystem services in agricultural landscapes-Are we asking the right questions? Agric. Ecosyst. Environ. 2004, 104, 113-134. [CrossRef]

104. Brussaard, L.; de Ruiter, P.C.; Brown, G.G. Soil biodiversity for agricultural sustainability. Agric. Ecosyst. Environ. 2007, 121, 233-244. [CrossRef]

105. Decaëns, T. Macroecological patterns in soil communities. Glob. Ecol. Biogeogr. 2010, 19, 287-302. [CrossRef]

106. Decaëns, T.; Jiménez, J.; Gioia, C.; Measey, G.; Lavelle, P. The values of soil animals for conservation biology. Eur. J. Soil Biol. 2006, 42, S23-S38. [CrossRef]

107. Martínez, P.; Narciso, E.V. Mesofauna. In Biología y Ecología de la Fauna Del Suelo, 1st ed.; Momo, F.R., Falco, L.B., Eds.; Imago Mundi: Buenos Aires, Argentina, 2009; pp. 9-21. (In Spanish)

108. Wall, D.H.; Bardgett, R.D.; Behan-Pelletier, V.; Herrick, J.E.; Jones, T.H.; Six, J.; Strong, D.R. Soil Ecology and Ecosystem Services; Oxford University Press: Oxford, UK, 2012.

109. Sagoff, M. The quantification and valuation of ecosystem services. Ecol. Econ. 2011, 70, 497-502. [CrossRef]

110. Adams, W.M. The value of valuing nature. Science 2014, 346, 549-551. [CrossRef] [PubMed]

111. Bardgett, R.; van der Putten, W. Belowground biodiversity and ecosystem functioning. Nature 2014, 515, 505-511. [CrossRef] [PubMed]

112. El Titi, A. Tillage in Agroecosystems, the synthesis. In Soil Tillage in Agroecosystems; El Titi, A., Ed.; CRC Press: Boca Raton, FL, USA, 2003; p. 384.

113. López, A.N.; Vincini, A.M.; Clemente, N.L.; Manetti, P.L.; Carmona, D.M.; Álvarez Castillo, H.A. Densidad estacional y distribución vertical de los Enchytraeidae (Annelida: Oligochaeta) en diferentes sistemas de producción. Ci Suelo 2005, 23, 115-121. (In Spanish)

114. Lietti, M.; Gamundi, J.C.; Montero, G.; Molinari, A.; Bulacio, V. Efecto de dos sistemas de labranza sobre la abundancia de artrópodos que habitan en el suelo. Ecol. Austral 2008, 18, 71-78. (In Spanish)

115. Gizzi, A.H.; Álvarez Castillo, H.A.; Manetti, P.L.; López, A.N.; Clemente, N.L.; Studdert, G.A. Caracterización de la meso y macrofauna edáfica en sistemas de cultivo del Sudeste Bonaerense. Ci Suelo 2009, 27, 1-9. (In Spanish)

116. Duhour, A.; Costa, C.; Momo, F.; Falco, L.; Malacalza, L. Response of earthworm communities to soil disturbance: Fractal dimension of soil and species' rank-abundance curves. Appl. Soil Ecol. 2009, 43, 83-88. [CrossRef]

117. Manetti, P.L.; López, A.N.; Clemente, N.L.; Faberi, A.J. Tillage system does not affect soil macrofauna in southeastern Buenos Aires province, Argentina. Span. J. Agric. Res. 2010, 8, 377-384. [CrossRef]

118. Masín, C.E.; Rodríguez, A.R.; Maitre, M.I. Evaluación de la abundancia y diversidad de lombrices de tierra en relación con el uso del suelo en el cinturón hortícola de Santa Fe (Argentina). Ci Suelo 2011, 29, $21-28$. (In Spanish)

119. Maitre, M.I.; Rodríguez, A.R.; Masín, C.E.; Ricardo, T. Chapter 2: Evaluation of earthworms present on natural and agricultural-livestock soils of the center northern litoral santafesino, República Argentina. InTech 2012. [CrossRef] 
120. Díaz Porres, M.; Rionda, M.; Duhour, A.; Momo, F.R. Artrópodos del suelo: Relaciones entre la composición faunística y la intensificación agropecuaria. Ecol. Austral 2014, 24, 327-334. (In Spanish)

121. Falco, L.B.; Sandler, R.; Momo, F.; Di Ciocco, C.; Saravia, L.; Coviella, C. Earthworm assemblages in different intensity of agricultural uses and their relation to edaphic variables. Peer] 2015. [CrossRef] [PubMed]

122. Bedano, J.C.; Domínguez, A.; Arolfo, R.; Wall, L.G. Effect of good agricultural practices under no-till on litter and soil invertebrates in areas with different soil types. Soil Tillage Res. 2016, 158, 100-109. [CrossRef]

123. Marasas, E.; Sarandón, S.J.; Cicchino, A. Efecto de la labranza sobre la coleopterofauna edáfica en un cultivo de trigo en la Provincia de Buenos Aires. Ci Suelo 1997, 15, 59-63. (In Spanish)

124. Marasas, E.; Sarandón, S.J.; Cicchino, A. Changes in soil arthropod functional group in a wheat crop under conventional and no tillage systems in Argentina. Appl. Soil Ecol. 2001, 18, 61-68. [CrossRef]

125. Manetti, P.L.; Faberi, A.J.; Clemente, N.L.; López, A.N. Macrofauna activity density in contrasting tillage systems in Buenos Aires Province, Argentina. Agron. J. 2013, 105, 1780-1786. [CrossRef]

126. Pilatti, M.A.; de Orellana, J.A.; Priano, L.J.; Felli, O.M.; Grenon, D.A. Incidencia de manejos tradicionales y conservacionistas sobre propiedades físicas, químicas y biológicas de un Argiudol en el sur de Santa Fé. Ci Suelo 1988, 6, 19-29. (In Spanish)

127. Gomez, M.; Krüger, H.; Sagardoy, M. Actividad biológica en un suelo de la zona semiárida bonaerense cultivado con la secuencia soja-trigo bajo tres prácticas culturales. Ci Suelo 1996, 14, 37-41. (In Spanish)

128. Bedano, J.C.; Ruf, A. Soil predatory mite communities (Acari: Gamasina) in agroecosystems of Central Argentina. Appl. Soil Ecol. 2007, 36, 22-31. [CrossRef]

129. Ferraro, D.O.; Ghersa, C.M. Exploring the natural and human-induced effects on the assemblage of soil microarthropod communities in Argentina. Eur. J. Soil Biol. 2007, 43, 109-119. [CrossRef]

130. Bedano, J.C.; Dominguez, A.; Arolfo, R. Assessment of soil biological degradation using mesofauna. Soil Tillage Res. 2011, 117, 55-60. [CrossRef]

131. The Degree of Change of Collembolan Community Structure Related to Anthropic Soil Disturbance. Available online: https:/ / peerj.com/preprints/721/ (accessed on 10 March 2016).

132. Bedano, J.C.; Ruf, A. Sensitivity of different taxonomic levels of soil Gamasina to land use and anthropogenic disturbances. Agric. For. Entomol. 2010, 12, 203-212. [CrossRef]

133. Gomiero, T.; Pimentel, D.; Paoletti, M. Environmental impact of different agricultural management practices: Conventional vs. organic agriculture. Crit. Rev. Plant. Sci. 2011, 30, 95-124. [CrossRef]

134. Gomiero, T. Alternative land management strategies and their impact on soil conservation. Agriculture 2013, 3, 464-483. [CrossRef]

135. Reganold, J.P.; Wachter, J.M. Organic agriculture in the twenty-first century. Nat. Plants 2015. [CrossRef] [PubMed]

136. Environmental Impact of Organic Agriculture. Available online: https://www.cabdirect.org/?target= $\% 2$ fcabdirect $\% 2$ fabstract $\% 2$ f20063178465 (accessed on 10 March 2016).

137. Crowder, D.W.; Reganold, J.P. Financial competitiveness of organic agriculture on a global scale. Proc. Natl. Acad. Sci. USA 2015, 24, 7611-7616. [CrossRef] [PubMed]

(C) 2016 by the authors; licensee MDPI, Basel, Switzerland. This article is an open access article distributed under the terms and conditions of the Creative Commons Attribution (CC-BY) license (http://creativecommons.org/licenses/by/4.0/). 